\title{
Copper storage protein from Streptomyces lividans
}

\author{
Jonathan AR Worrall
}

School of Life Sciences, University of Essex, Wivenhoe Park, Colchester, UK

\section{FUNCTIONAL CLASS}

Protein; widespread in bacteria; multicuprous ion-binding sites; referred to as copper storage protein.

Bacterial copper storage proteins (Csps) belong to the DUF326 superfamily (PF03860) (DUF domain of unknown function) that contain a cysteine-rich repeat that mostly follows the pattern Cys- $\mathrm{X}_{2}$-Cys- $\mathrm{X}_{3}-$ Cys- $\mathrm{X}_{2}$-Cys-X. Their functional state comprises a homotetramer assembly of four-helix bundle motifs. Depending on their cellular location, that is periplasmic or cytosolic, they have the capacity to bind between 13 and 20 cuprous ions per fourhelix bundle (52-80 cuprous ions per homotetramer) predominantly through thiolate coordination chemistry. Their apparent $\mathrm{Cu}^{\mathrm{I}}$-binding affinities are in the subfemtomolar range.

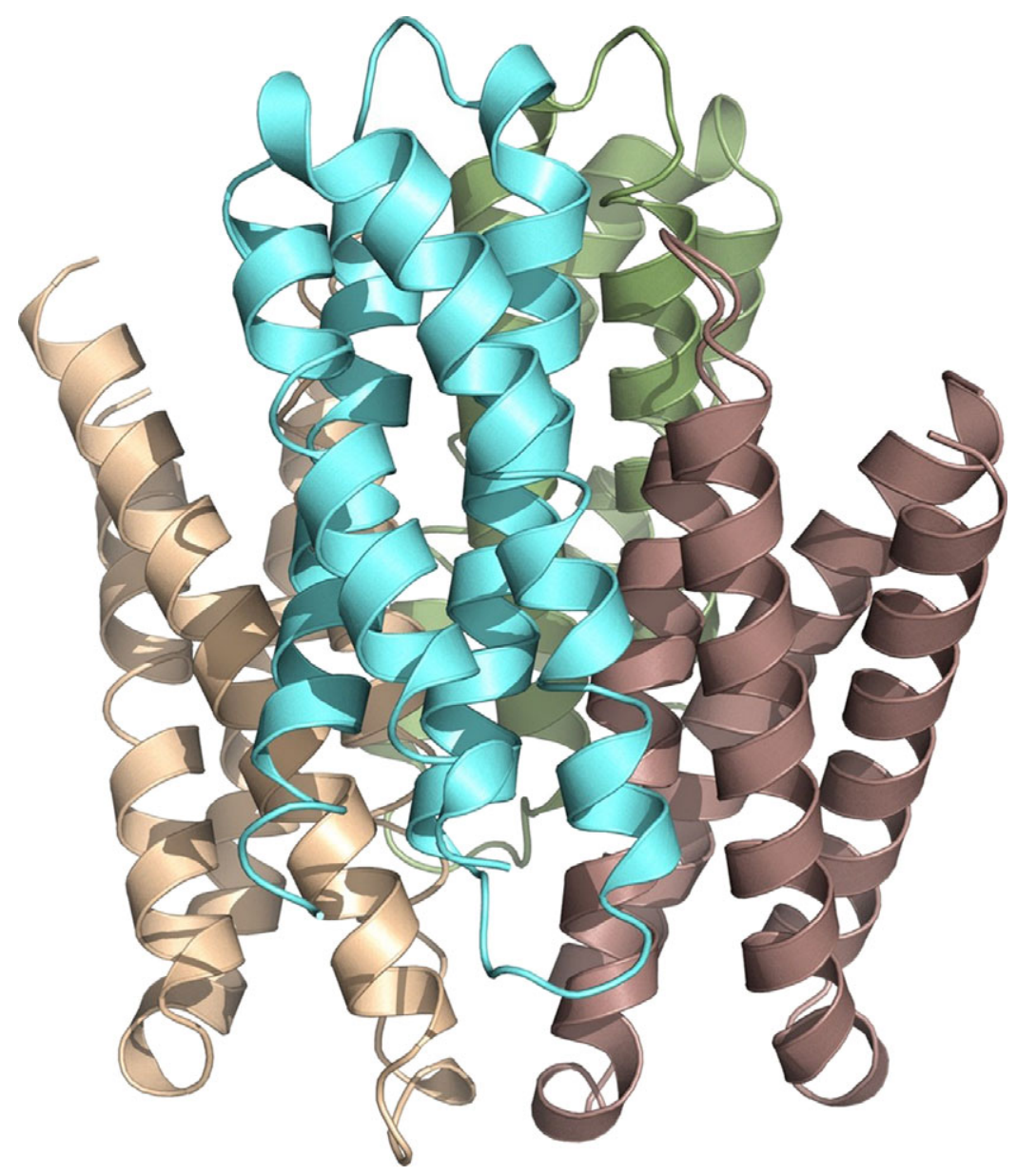

3D Structure Cartoon representation of the homotetramer assembly of the copper storage protein form Streptomyces lividans, PDB code: $6 \mathrm{EI} 0 .{ }^{1}$ Each four-helix bundle (protomer) of the functional assembly is individually colored. [Based on ML Straw, AK Chaplin, MA Hough, J Paps, VN Bavro, MT Wilson, E Vijgenboom, JAR Worrall, Metallomics, 10, 180-193 (2018).] 


\section{OCCURRENCE}

Csps were first discovered in the Gram-negative methaneoxidizing bacterium, Methylosinus trichosporium OB3b. ${ }^{2}$ Two Csps, initially named Csp1 and Csp2, were found to contain a twin-arginine translocase (Tat) signal peptide, signifying their export to the periplasm in a folded state. A third Csp, not possessing a Tat signal peptide, was also identified in M. trichosporium OB3b and named Csp3. ${ }^{2}$ The absence of a Tat signal peptide implies that Csp3 is not exported and remains in the cytosol. M. trichosporium OB3b Csp1 and Csp2 were later renamed Csp1a and $1 \mathrm{~b}$, respectively, to signify exported Csps homologues with a similar function. ${ }^{3}$ The taxonomic distribution of Csp3s reveals them to be more widespread in bacteria than the Csp1 homologues. ${ }^{1-3}$ At least seven Bacterial groups contain Csp3, and they are also found within two of the major Archaea groups. ${ }^{1}$ Recombinant Csp1a and Csp3 from M. trichosporium OB3b have been purified and extensively characterized, ${ }^{2,4}$ as have two Csp3 members from the nonmethanotrophic Gram-positive bacteria, Bacillus subtilis ${ }^{4}$ and Streptomyces lividans. ${ }^{1}$ The latter $(\mathrm{SlCsp} 3)$ is the subject of this article.

\section{BIOLOGICAL FUNCTION}

Methanotrophic bacteria oxidize methane to $\mathrm{CO}_{2}$ via methanol, formaldehyde, and formate. To catalyze the oxidation of methane to methanol either the membranebound particulate methane monooxygenase (pMMO) or soluble methane monooxygenase (sMMO) is used.5,6 pMMO is located within extensive intracytoplasmic membranes and is a cuproenzyme (see Particulate Methane Monooxygenase), ${ }^{7-11}$ whereas sMMO is located in the cytoplasm and contains a diiron active site (see Methane Monooxygenase Hydroxylase). ${ }^{12,13}$ In organisms containing genes for both sMMO and pMMO, the regulation of sMMO is controlled by a mechanism referred to as the 'copper switch' whereby sMMO is expressed under low copper conditions, but under copper replete conditions is downregulated. ${ }^{6,7,14-17}$ When methanotrophs use pMMO to oxidize methane it can account for up to $20 \%$ of the total protein content of the cell, and thus a significant requirement of copper is needed by the organism. ${ }^{16-19}$ To cope with this large requirement for copper, small peptidic copper chelators, called methanobactins $(\mathrm{Mbn})$, are secreted to scavenge for copper, with $\mathrm{Cu}-\mathrm{Mbn}$ reinternalized into the methanotroph. ${ }^{17,20-22}$ Metalloproteomic studies using the copper-switching organism M. trichosporium $\mathrm{OB} 3 \mathrm{~b}$ designed to determine the fate of the reinternalized $\mathrm{Cu}-\mathrm{Mbn}$ surprisingly found no evidence for the presence of apo-Mbn or $\mathrm{Cu}-\mathrm{Mbn}$ but instead identified soluble copper pools associated with the Tat-exported Csp1 homologues. ${ }^{2}$
Several further lines of study concluded that Csp1s act as a $\mathrm{Cu}^{\mathrm{I}}$ store for $\mathrm{pMMO}$ to maintain its use for methane metabolism under low copper levels. ${ }^{2}$

In contrast, the exact function of bacterial Csp3s remains under debate. ${ }^{3,23}$ If not carefully regulated, $\mathrm{Cu}^{\mathrm{I}}$ can be highly toxic in the reducing environment of the bacterial cytosol. ${ }^{24}$ Based on the Irving-Williams series of metal-binding preferences, ${ }^{25}$ copper and particularly $\mathrm{Cu}^{\mathrm{I}}$ will readily displace or outcompete the cognate metal for a binding site, as has been exemplified for iron in $\mathrm{Fe}-\mathrm{S}$ clusters, ${ }^{26-29}$ leading to detrimental effects on the cell. For this reason, copper-specific bacterial regulatory systems are prevalent that act to rapidly efflux excess $\mathrm{Cu}^{\mathrm{I}}$ out of the cytosol. $^{24,30}$ The presence of such systems has helped support the view that a metabolic requirement for cuproenzymes in the bacterial cytosol does not exist. However, with the discovery of Csp3s, it would appear that the handling of copper in the bacterial cytosol is perhaps more complicated, and elucidating their role in connection to preventing toxicity and/or in copper storage for metabolic use has been the subject of recent studies. ${ }^{1,4,31}$

\section{DEPOSITED X-RAY STRUCTURES OF Csp3s IN THE PROTEIN DATA BANK}

Several X-ray structures of Csp3 members have been deposited in the protein data bank (PDB), which include structures of apo and cuprous ion-loaded forms, structures of amino-acid variants, and structures determined following varying substoichiometric additions of cuprous ions (Table 1). Two of the deposited X-ray structures reported in Table 1, Pseudomonas aeruginosa Csp3 (PaCsp3) and Nitrosospira multiformis $\mathrm{Csp} 3$ ( $\mathrm{Nm} \mathrm{Csp} 3$ ), were deposited to the PDB in 2009 and 2010, respectively, by the Northeast Structural Genomics Consortium (NESG). The deposition of these structures preceded the discovery and first report of the Csp family. ${ }^{2}$

\section{AMINO ACID SEQUENCE INFORMATION}

- S. lividans 1326, 136 amino acids, UniProtKB entry D6ES11, Q9X8F4

- B. subtilis, 108 amino acids, UniProtKB entry O07571, sequence identity with $\mathrm{SlCsp} 338 \%$

- P. aeruginosa, 134 amino acids, UniProtKB entry Q91208, sequence identity with SlCsp3 31\%

- N. multiformis, 113 amino acids, UniProtKB entry Q2Y879, sequence identity with SlCsp3 27\%

- M. trichosporium OB3b, 133 amino acids, no UniProtKB entry, sequence identity with $S l C s p 348 \%$. 
Table 1 X-ray crystal structures deposited in the PDB for various Csp3 members

\begin{tabular}{|c|c|c|c|}
\hline Organism & $\begin{array}{l}\text { PDB code and } \\
\text { resolution }\end{array}$ & $\begin{array}{l}\text { Description of structure } \\
\text { deposited }\end{array}$ & $\begin{array}{l}\text { Number of } \\
\text { Cys residues } \\
\text { per four-helix } \\
\text { bundle }\end{array}$ \\
\hline \multirow{7}{*}{$\begin{array}{l}\text { Streptomyces lividans } \\
\text { (S/Csp3) }\end{array}$} & $6 \mathrm{EI0}, 1.34 \AA$ & apo state & 18 \\
\hline & $6 \mathrm{EK} 9,1.50 \AA$ & $20 \mathrm{Cu}^{\prime}$ ions bound & \\
\hline & $6 Q Y B, 1.20 \AA$ & $\mathrm{H} 111 \mathrm{~A}$ variant, $19 \mathrm{Cu}^{\prime}$ ions bound & \\
\hline & $6 Q V H, 1.30 \AA$ & $\mathrm{H} 113 \mathrm{~A}$ variant, $20 \mathrm{Cu}^{\prime}$ ions bound & \\
\hline & $6 \mathrm{R} 01,1.20 \AA$ & $\mathrm{H} 107 \mathrm{~A} / \mathrm{H} 111 \mathrm{~A}$ variant, $19 \mathrm{Cu}^{\prime}$ ions bound & \\
\hline & $6 Q 58,1.50 \AA$ & $5 \mathrm{Cu}^{\prime}$ equivalents added, partial occupancies & \\
\hline & $6 \mathrm{QB}, 1.90 \AA$ & $10 \mathrm{Cu}^{\prime}$ equivalents added, partial occupancies & \\
\hline \multirow{5}{*}{$\begin{array}{l}\text { Methylosinus trichosporium } \\
\text { OB3b (MtCsp3) }\end{array}$} & 5ARM, $1.19 \AA$ & apo state & 19 \\
\hline & $5 A R N, 2.30 \AA$ & $19 \mathrm{Cu}^{\prime}$ ions bound & \\
\hline & $5 N Q M, 1.59 \AA$ & 1-2 Cu' equivalents added, partial occupancies & \\
\hline & $5 N Q N, 1.62 \AA$ & $8 \mathrm{Cu}$ ' equivalents added, partial occupancies & \\
\hline & $5 \mathrm{NQO}, 1.15 \AA$ & $14 \mathrm{Cu}^{\prime}$ equivalents added, partial occupancies & \\
\hline Bacillus subtilis (BsCsp3) & $5 F I G, 1.7 \AA$ & apo state & 19 \\
\hline \multirow{2}{*}{$\begin{array}{l}\text { Pseudomonas aeruginosa } \\
\qquad(P a C s p 3)\end{array}$} & 3KAW, $2.40 \AA$ & apo state & 12 \\
\hline & $3 \mathrm{KAV}, 2.50 \AA$ & L80M variant, apo state & \\
\hline $\begin{array}{l}\text { Nitrosospira multiformis } \\
\quad(\mathrm{NmCsp} 3)\end{array}$ & 3LMF, $2.30 \AA$ & apo state & 16 \\
\hline
\end{tabular}

[Data available from the PDB (protein data bank).]

\section{PROTEIN PRODUCTION AND PURIFICATION}

A recombinant Escherichia coli overexpression system for SlCsp3 has been reported, ${ }^{1}$ which produces an $\mathrm{N}$-terminal $\mathrm{His}_{6}$-tagged $\mathrm{SlCsp} 3$ fusion protein from a pET28a plasmid under the control of a T7 promoter. The overexpressed SlCsp3 is subsequently purified using a high-pressure homogenizer to rupture the cytosolic membrane, followed by centrifugation and application of the supernatant containing the soluble $\mathrm{His}_{6}$-tagged SlCsp3 fusion protein to an immobilized nickel chromatography column. ${ }^{1}$ Cleavage of the $\mathrm{N}$-terminal $\mathrm{His}_{6}$-tag from the $\mathrm{SlCsp} 3$ protein is carried out using the serine protease, thrombin, followed by size-exclusion chromatography (Sephadex G75 resin). The SlCsp3 elutes from the Sephadex G75 column at a retention volume consistent with a protein of mass corresponding to a homotetramer assembly.

\section{MOLECULAR CHARACTERIZATION}

The N-terminal sequence of recombinant SlCsp3 retains three additional residues (Gly-Ser-His-MetSlCsp3) before the Met1 following cleavage of the $\mathrm{His}_{6}$-tag. On denaturing gel electrophoresis, a single Coomassie-stained band is observed that runs at a molecular weight corresponding to $\sim 15 \mathrm{kDa}$. Under denaturing conditions, electrospray ionization mass spectrometry (ESI-MS) reports a mass for the recombinant $S l \mathrm{Csp} 3$ of $14604.6 \mathrm{Da}$, corroborating the presence of the $\mathrm{N}$-terminal Gly-Ser-His sequence. ${ }^{1}$ Application of SlCsp3 to native ESI-MS leads to the identification of a dominant species with a mass of $58418.16 \mathrm{Da}$, consistent with $\mathrm{SlCsp} 3$ existing in solution as a homotetramer assembly, that is four protomers, consistent with the elution profile from size-exclusion chromatography. ${ }^{1}$ Notably, the mass obtained from native ESI-MS is accountable for only the protein, and thus the recombinant SlCsp3 does not purify with bound copper ions. ${ }^{1}$

\section{SPECTROSCOPY OF SICsp3}

Addition of cupric ions to the as-purified $S l \mathrm{Csp} 3$ results in no spectral changes in either the ultraviolet (UV) or visible regions of the electronic absorbance spectrum. To assess cuprous ion binding to $\mathrm{SlCsp} 3$, strict anaerobic conditions are required, with stock $\mathrm{Cu}^{\mathrm{I}}$ concentrations first determined spectrophotometrically through titration to a known concentration of the $\mathrm{Cu}^{\mathrm{I}}$-specific bidentate ligand, bicinchoninic acid (BCA) (Figure 1(a)). Formation of the $\left[\mathrm{Cu}(\mathrm{BCA})_{2}\right]^{3-}$ complex gives an electronic absorbance spectrum with a $\lambda_{\max }$ at $562 \mathrm{~nm}$ and an extinction coefficient $(\varepsilon)$ of $7900 \mathrm{M}^{-1} \mathrm{~cm}^{-1}$ (Figure $1(\mathrm{~b})$ ), 


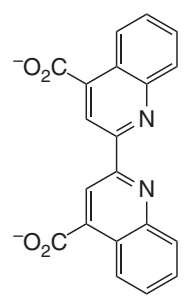

(a)

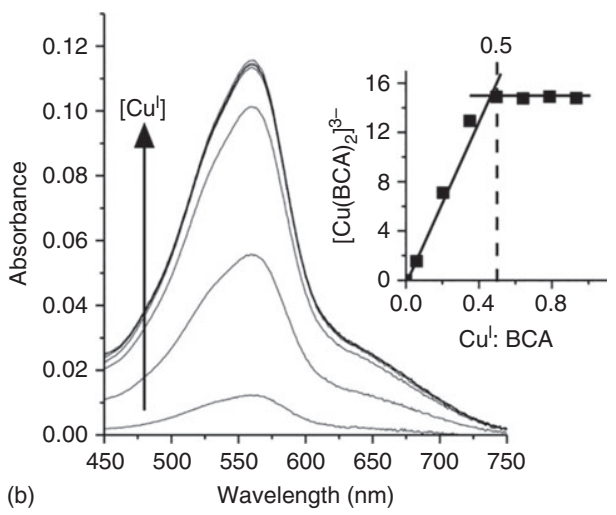

Figure 1 (a) Chemical structure of [2,2-biquinoline]-4, $4^{\prime}$ dicarboxylic acid, commonly referred to as bicinchoninic acid (BCA). (b) Absorbance spectra obtained by titrating a $\mathrm{CuCl}$ solution into a known concentration of BCA. The absorbance increase at $562 \mathrm{~nm}$ is linear with a sharp turning point at a $\mathrm{Cu}^{\mathrm{I}}: \mathrm{BCA}$ of 0.5 (inset), indicating the formation of a $1: 2\left[\mathrm{Cu}(\mathrm{BCA})_{2}\right]^{3-}$ complex.

enabling for stock $\mathrm{Cu}^{\mathrm{I}}$ concentrations to be determined upon saturation of the BCA ligand $\left(\mathrm{Cu}^{\mathrm{I}}\right.$ :BCA stoichiometry of 0.5 , Figure 1 (b) inset). ${ }^{32}$ Titration of $\mathrm{Cu}^{\mathrm{I}}$ to SlCsp3 results in the gradual appearance in the UV region of the spectrum of $(\mathrm{Cys}) \mathrm{S} \gamma \rightarrow \mathrm{Cu}^{\mathrm{I}}$ ligand-to-metal charge transfer (LMCT) bands (Figure 2(a)), which increase concomitantly with increasing $\left[\mathrm{Cu}^{\mathrm{I}}\right]$ until a saturation point is reached coinciding with a stoichiometry of between 18 and 20 bound $\mathrm{Cu}^{\mathrm{I}}$ ions per SlCsp3 protomer (Figure 2(b)). ${ }^{1}$ Thus, $\sim 80 \mathrm{Cu}^{\mathrm{I}}$ ions can bind per SlCsp3 homotetramer.

\section{X-RAY STRUCTURE OF SICsp3 Crystallization}

Crystals of the apo and $\mathrm{Cu}^{\mathrm{I}}$-loaded forms of $S l \mathrm{Csp} 3$ were grown from $1.4 \mathrm{M}$ ammonium sulfate solutions buffered with either 0.1 M HEPES (2-[4-(2-hydroxyethyl)piperazin1-yl]ethanesulfonic acid), $\mathrm{pH} 7.0$, for the apo form or $0.1 \mathrm{M}$ MES (2-(N-morpholino)ethanesulfonic acid), $\mathrm{pH} 6.0$, for the $\mathrm{Cu}^{\mathrm{I}}$-loaded form. $\mathrm{Cu}^{\mathrm{I}}$-loaded samples for crystallization were prepared by the addition of a 25 -fold excess over apo protein concentration of $\mathrm{Cu}^{\mathrm{I}}$ ions with unbound $\mathrm{Cu}^{\mathrm{I}}$ removed using a desalting column. ${ }^{1}$ Crystals of the apo protein had a hexagonal lattice and a $P 6_{1} 22$ space group with a unit cell of $a=93.6 \AA, b=93.6 \AA$, and $c=213.4 \AA$ $(1 \AA=0.1 \mathrm{~nm})$ that contained four protomers (i.e. 4 fourhelix bundle motifs) in the asymmetric unit. In the case of the $\mathrm{Cu}^{\mathrm{I}}$-loaded protein, crystals had an orthorhombic lattice and an $I 222$ space group with a unit cell of $a=93.6 \AA, b=93.6 \AA$, and $c=213.4 \AA$ and one protomer in the asymmetric unit. The apo and $\mathrm{Cu}^{\mathrm{I}}$-loaded structures
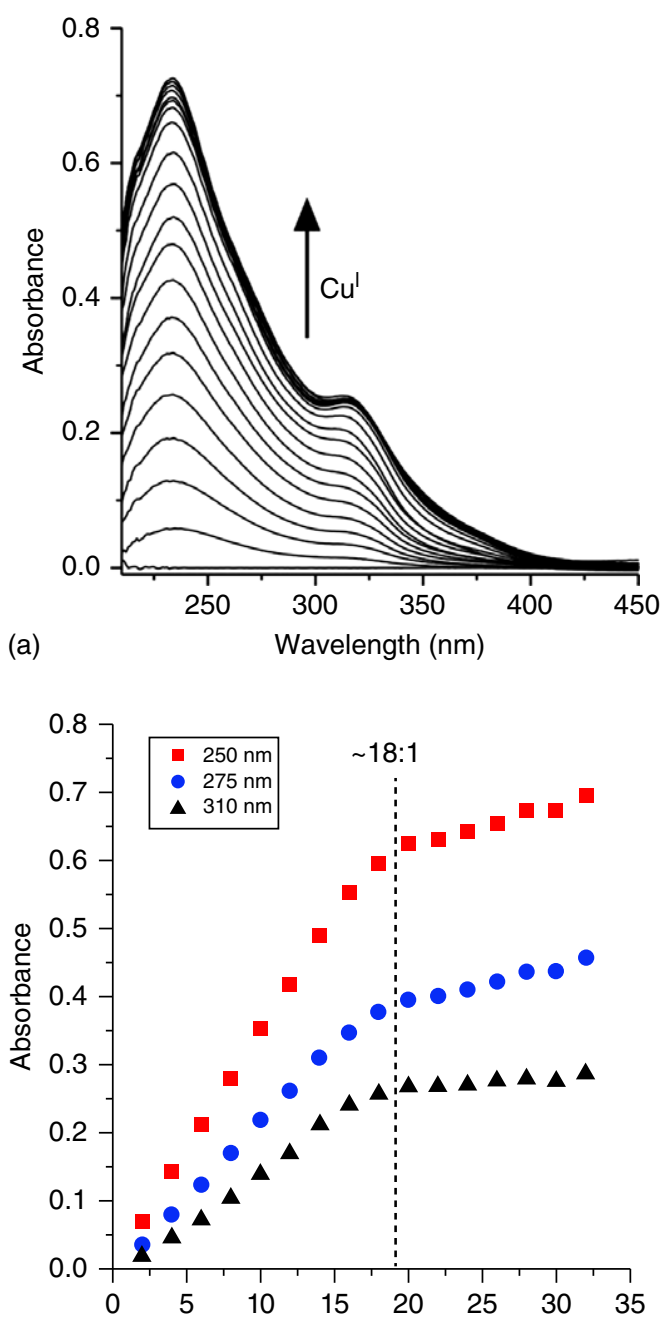

(b)

Cul:S/Csp3

Figure 2 UV-absorbance spectroscopy and stoichiometry of $\mathrm{Cu}^{\mathrm{I}}$ binding to $\mathrm{SlCsp} 3$ at $\mathrm{pH}$ 7.5. (a) UV spectral changes for SlCsp3 upon addition of increasing stoichiometries of cuprous ions. (b) Absorbance changes for selected wavelengths plotted as a function of the $\mathrm{Cu}^{\mathrm{I}}$ :SlCsp 3 ratio. The dashed lines indicate a break point in the titration where the stoichiometry of $\mathrm{Cu}^{\mathrm{I}}$ binding can be estimated. ${ }^{1}$ [Straw, M. L., Chaplin, A. K., Hough, M. A., Paps, J., Bavro, V. N., Wilson, M. T., Worrall, J. A. R. (2018). A cytosolic copper storage protein provides a second level of copper tolerance in Streptomyces lividans. Metallomics, 10(1), 180-193.]

were determined using molecular replacement and refined to a resolution of 1.34 and $1.50 \AA$, respectively (Table 1$).{ }^{1}$

\section{Structure of apo SICsp3}

Each of the four protomers present in the crystallographic asymmetric unit of apo $S l C s p 3$ exclusively comprises four $\alpha$-helices, which pack together lengthways in an antiparallel 
(a)

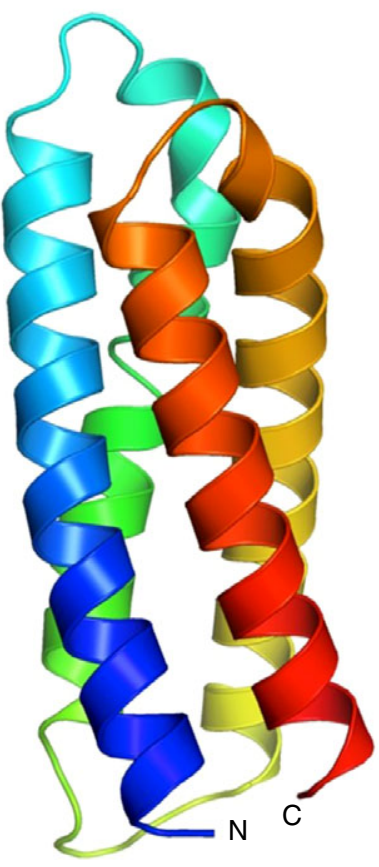

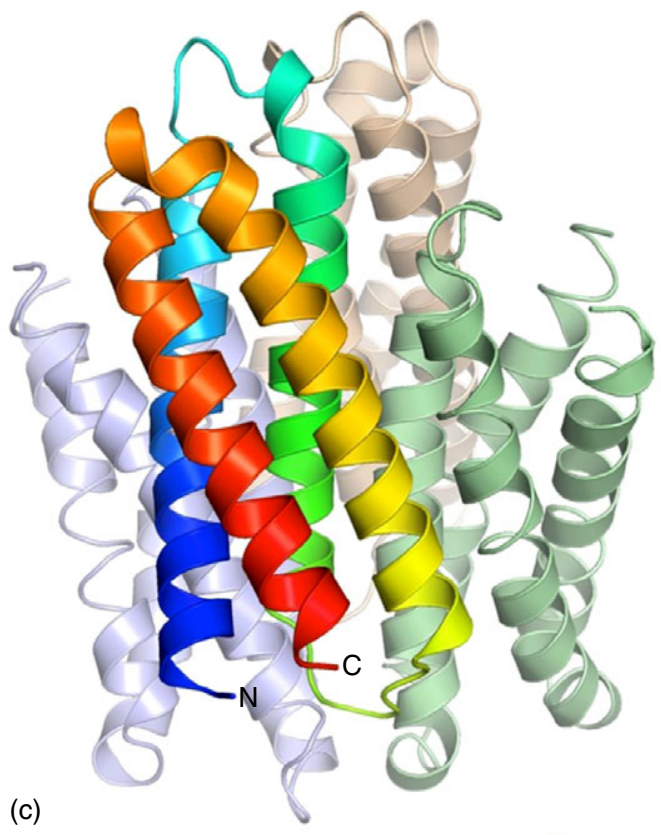

(c)

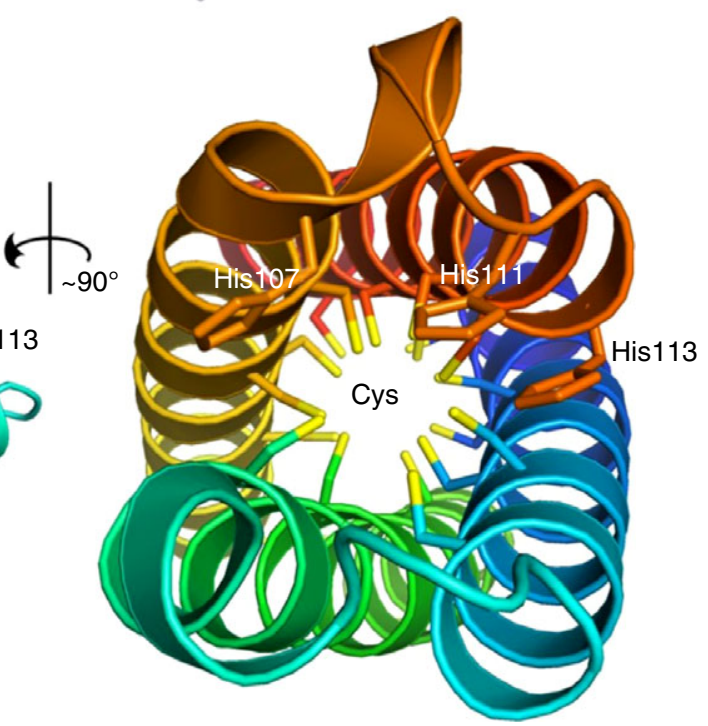

(b)

Figure 3 Cartoon representation of the X-ray structure of apo SlCsp3 (PDB code: 6EI0). ${ }^{1}$ (a) The up-down-up-down topology of the four-helix bundle (protomer) with the N and C termini labeled. (b) Side-on and core views of the four-helix bundle. The three His residues at the entrance to the core and the Cys residues lining the core are shown in stick representation. (c) The functional homotetramer assembly of SlCsp3. [Based on ML Straw, AK Chaplin, MA Hough, J Paps, VN Bavro, MT Wilson, E Vijgenboom, JAR Worrall, Metallomics, 10, 180-193 (2018).]

manner to give a four-helix bundle motif with an updown-up-down topology (Figure $3(\mathrm{a}))^{1}{ }^{1}$ The dimensions of the four-helix bundle are $\sim 29 \times 47 \times 38 \AA$. The 18 Cys residues present in $\mathrm{SlCsp} 3$ face inward into the solventexcluded core of the bundle (Figure 3(b)). ${ }^{1}$ Notably, Csp3s have a higher proportion of Cys residues compared to Csp1s, suggesting a higher $\mathrm{Cu}^{\mathrm{I}}$ storage capacity. ${ }^{1,4,33}$ No disulfide bonds or chemical modifications to any of the Cys residues were observed in the crystal structure, and thus all Cys thiolates are free to coordinate a $\mathrm{Cu}^{\mathrm{I}}$ ion. At one end of the four-helix bundle, access to the Cys core is via an opening lined with hydrophilic residues, dominated by a triad of His residues (Figure 3(b)), which are highly conserved across Csp3 members. ${ }^{1,4,33}$ At the opposite end of the His triad, a stretch of hydrophobic side chains must be navigated before access to the Cys core is reached, and thus the His entrance is favored for $\mathrm{Cu}^{\mathrm{I}}$ ion entry (vide infra).

In solution, the functional structure of $\mathrm{SlCsp3}$ is a homotetramer (Figure 3(c)), with the dimensions of $\sim 55 \times 61 \times 55 \AA$. The total solvent-accessible surface area of the homotetramer assembly is $17320 \AA^{2}$, with a buried area, defined as the total solvent-accessible surface 
area buried upon formation of all assembly interface, of $8105 \AA^{2} .^{34}$ Thus, nearly $50 \%$ of the total accessible solvent surface area of the tetramer is part of the interface between protomers. This is reflected in the following thermodynamic parameters: the solvation free energy gain upon formation of the assembly, $\Delta G^{\text {Int }}=-53.2 \mathrm{kcalmol}^{-1}$ and the free energy of assembly dissociation, $\Delta G^{\text {diss }}=24.4 \mathrm{kcal} \mathrm{mol}^{-1}$, where the large negative $\Delta G^{\text {Int }}$ value and a $\Delta G^{\text {diss }} \gg 0$ implies a highly thermodynamically stable functional assembly. ${ }^{34}$

\section{Coordination chemistries of the Cu'-loaded SICsp3}

The positions of the cuprous ions in the X-ray structure of the $\mathrm{Cu}^{\mathrm{I}}$-loaded $S l \mathrm{Csp} 3$ were identified from anomalous difference maps. ${ }^{1}$ These revealed well-defined electron density (a)
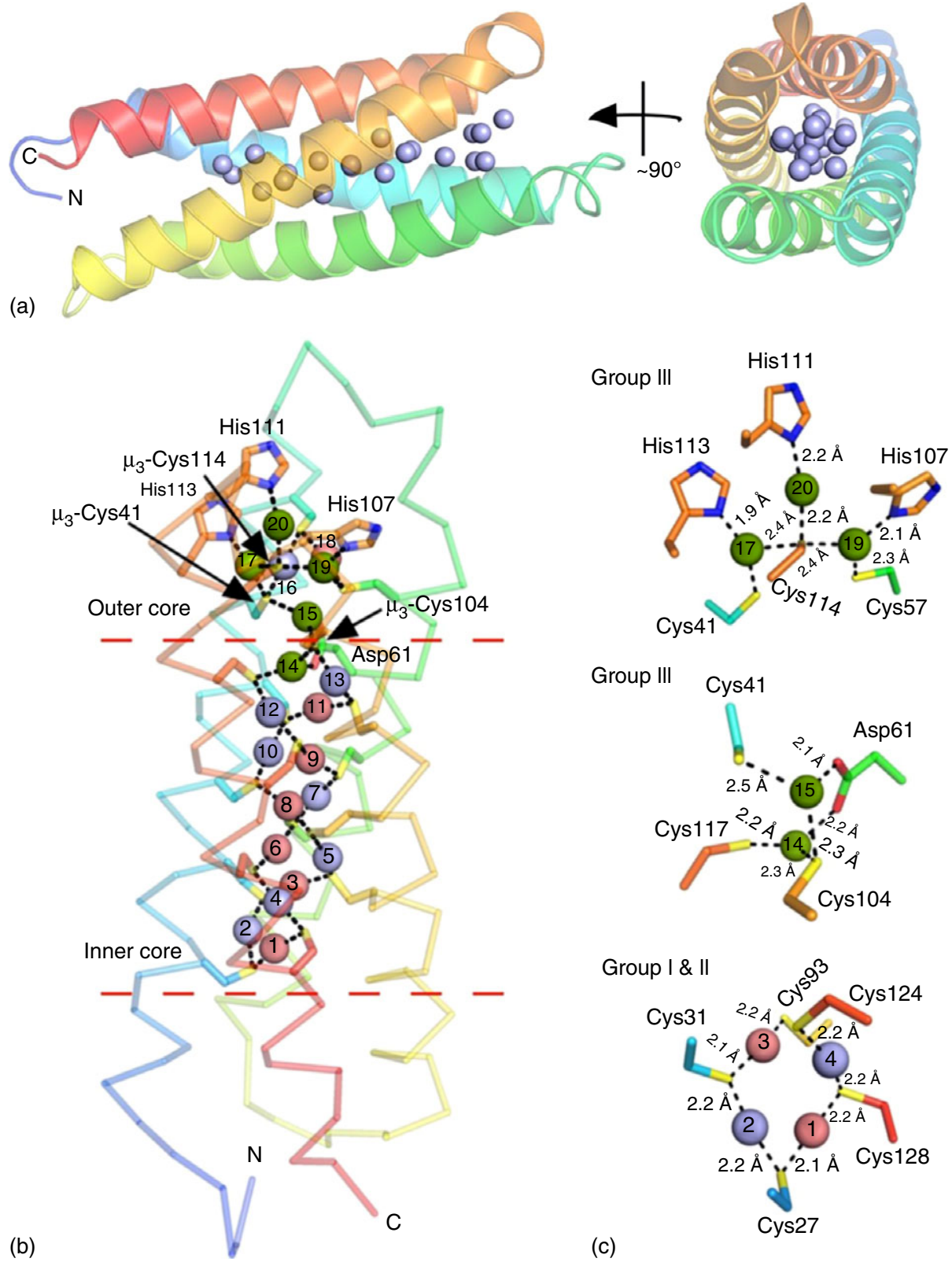

Group III
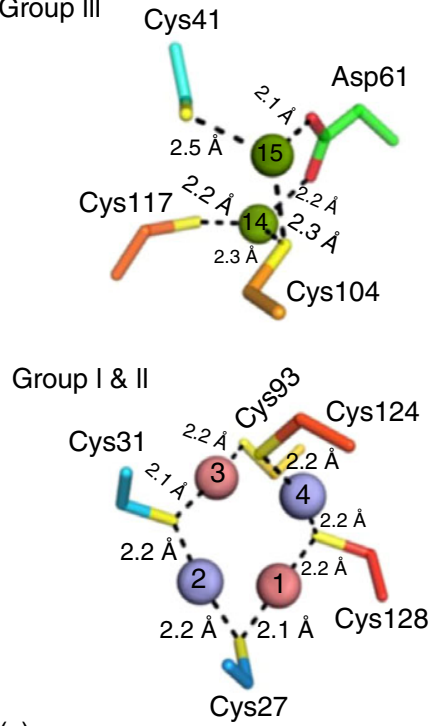

(c)

Figure 4 The X-ray structure of $\mathrm{Cu}^{\mathrm{I}}$-loaded SlCsp3 (PDB code: $\left.6 \mathrm{EK} 9\right){ }^{1}$ (a) Spatial positions of the 20 cuprous ions (spheres) bound in a protomer. (b) An overall view of the coordination chemistry of the bound $\mathrm{Cu}^{\mathrm{I}}$ ions in the outer and inner cores of a protomer. The $\mathrm{Cu}$ ions (spheres) are color coded according to their coordination group classification: group I, blue; group II, pink; group III, green. The Cys residues that participate in $\mu_{3}$-S-Cys coordination chemistry are labeled. (c) Specific examples of coordination chemistry among the different groups, with bond distances between the $\mathrm{Cu}^{\mathrm{I}}$ ions and respective ligand indicated. [Based on ML Straw, AK Chaplin, MA Hough, J Paps, VN Bavro, MT Wilson, E Vijgenboom, JAR Worrall, Metallomics, 10, 180-193 (2018).]

Encyclopedia of Inorganic and Bioinorganic Chemistry, Online @ $2011-2021$ John Wiley \& Sons, Ltd.

This article was published in the Encyclopedia of Inorganic and Bioinorganic Chemistry in 2021 by John Wiley \& Sons, Ltd. DOI: 10.1002/9781119951438.eibc2777 
Table 2 The cuprous ions in S/Csp3 that participate in the three classified coordination groups and the 15 copper ions that make up the nine $\mathrm{Cu}(\mathrm{I})-\mathrm{Cu}(\mathrm{I})$ interactions

\begin{tabular}{llll}
\hline $\begin{array}{l}\text { Coordination } \\
\text { group }\end{array}$ & Cu' number & Cu'-Cu' interaction & Distance (Å) \\
\hline Group I & Cu2, Cu4, Cu5, Cu7, Cu10, Cu12, Cu13, Cu16 & Cu1-Cu2 & 2.8 \\
Group II & Cu1, Cu3, Cu6, Cu8, Cu9, Cu11, Cu18 & Cu4-Cu6 & 2.6 \\
Group III & Cu14, Cu15, Cu17, Cu19, Cu20 & Cu7-Cu8 & 2.8 \\
& & Cu9-Cu10 & 2.8 \\
& & Cu13-Cu14 & 2.7 \\
& & Cu14-Cu15 & 2.8 \\
& & Cu16-Cu17 & 2.5 \\
\hline
\end{tabular}

[Based on ML Straw, AK Chaplin, MA Hough, J Paps, VN Bavro, MT Wilson, E Vijgenboom, JAR Worrall, Metallomics, 10, 180-193 (2018).]

for 20 cuprous ions filling the core of the four-helix bundle, ${ }^{1}$ thus confirming earlier titration data (Figure $2(\mathrm{~b})$ ) and implying that the functional homotetramer has the capacity to bind a total of 80 cuprous ions. Csps are the only example in biology where the four-helix bundle fold is utilized to be completely filled with metal ions. Other examples of metalloproteins and enzymes that utilize a four-helix bundle fold are ferritins (see Ferritin) ${ }^{35}$ and sMMO (see Methane Monooxygenase Hydroxylase), ${ }^{12}$ both of which house a diiron center and cytochrome $b_{562}$ (see $\boldsymbol{b}$-Type Cytochrome Electron Carriers: Cytochromes $b_{562}$ and $b_{5}$, and Flavocytochrome $\left.b_{2}\right),{ }^{36}$ which houses a single heme group. The spatial positions of the $20 \mathrm{Cu}^{\mathrm{I}}$ ions in the core are shown in Figure 4(a) and have been divided into either the inner $(\mathrm{Cu}$ sites $1-14)$ or the outer ( $\mathrm{Cu}$ sites 15-20) cores (Figure 4(b)). ${ }^{1}$ All Cys residues coordinate the cuprous ions via the $S \gamma$ atom, with the $\mathrm{O} \delta$ and N $\delta 1$ atoms from an Asp and three His residues, respectively, also contributing to the coordination sphere of several $\mathrm{Cu}^{\mathrm{I}}$ ions (Figure 4(b)). Within the two cores, cuprous ion coordination has been grouped based on differences in the coordination environment of the $\mathrm{Cu}^{\mathrm{I}}$ ion (Figure 4(c)). In group $\mathrm{I}, \mathrm{Cu}^{\mathrm{I}}$ ions are coordinated by two Cys thiolates in a CXXXC motif on the same helix. In group II, by two Cys thiolates on different helices of the four-helix bundle, and in group III, by Cys thiolates and either Asp or His residues (Figure 4(c)). ${ }^{1}$ The $\mathrm{Cu}^{\mathrm{I}}$ ions assigned to each coordination group are reported in Table 2. ${ }^{1}$ At sites $1-13$, the coordinating Cys residues bridge between two $\mathrm{Cu}^{\mathrm{I}}$ ions ( $\mu_{2}$-S-Cys) with bond lengths varying between 2.0 and $2.3 \AA$ (Figure $4(\mathrm{~b})$ and (c)). The group III Cu14 and Cu15 ions have a three-coordinate trigonal geometry arising from two Cys residues and the carboxylate O8 atoms of Asp61 (Figure 4(c)). In other Csp3 members, the Asp can be replaced by an Asn, but O coordination is still possible. ${ }^{4} \mathrm{Cu} 17$ and $\mathrm{Cu} 19$ (group III) also have three-coordinate trigonal geometries, with the third ligand derived from the N81 atom of His113 and His107, respectively (Figure 4(c)). The third His in the triad, His111, also participates in $\mathrm{Cu}^{\mathrm{I}}$ coordination to $\mathrm{Cu} 20$ (group III); however, this cuprous ion is not trigonally coordinated and is the only $\mathrm{Cu}^{\mathrm{I}}$ ion not to have bis-Cys coordination (Figure 4(c)). ${ }^{1}$ Instead, Cu20 adopts a near linear geometry with thiolate coordination from Cys114 (Figure 4(c)). Finally, three of the 18 Cys residues in SlCsp3, Cys41, Cys104, and Cys114, each bridge three cuprous ions $\left(\mu_{3}-\right.$ S-Cys); $\mu_{3}$-S-Cys ${ }^{37}-\mathrm{Cu} 15-16-17 ; \mu_{3}$-S-Cys ${ }^{104}$-Cu13-14-15; $\mu_{3}$-S-Cys ${ }^{114}$-Cu17-19-20 (Figure 4(b) and (c)).

A $\mathrm{Cu}^{\mathrm{I}}$ to $\mathrm{Cu}^{\mathrm{I}}$ distance of $\leq 2.8 \AA$ can be considered to have some metal-metal bonding character as the van der Waals radius of copper is $1.4 \AA$. In $S l C s p 3,15$ out of the 20 coordinated cuprous ions have $\mathrm{Cu}^{\mathrm{I}}-\mathrm{Cu}^{\mathrm{I}}$ distances between 2.5 and $2.8 \AA$ (Table 2), resulting in a total of nine $\mathrm{Cu}^{\mathrm{I}}-\mathrm{Cu}^{\mathrm{I}}$ interactions (Table 2). ${ }^{1}$

\section{FUNCTIONAL ASPECTS}

\section{Determination of an apparent $\mathrm{Cu}^{\prime}$-binding constant for SICsp3}

An estimation of apparent $\mathrm{Cu}^{\mathrm{I}}$-binding affinities in cuproproteins is most accurately determined through competition experiments using high-affinity chromogenic $\mathrm{Cu}^{\mathrm{I}}$ bidentate ligands such as BCA (Figure 1(a)) under strict anaerobic conditions. ${ }^{38}$ The formation of the $\left[\mathrm{Cu}(\mathrm{BCA})_{2}\right]^{3-}$ complex has reported an overall formation constant $\left(\beta_{2}\right)$ of $\log 17.7$, which is essentially $\mathrm{pH}$ independent at $\mathrm{pH} \geq 7.0 .{ }^{39}$ To obtain an apparent $\mathrm{Cu}^{\mathrm{I}}$-binding affinity for SlCsp3, a series of titration experiments were undertaken where the protein and BCA concentration remained fixed, but the $\left[\mathrm{Cu}^{\mathrm{I}}\right]$ varied. ${ }^{1}$ At $\mathrm{BCA}$ concentrations of 50 and $100 \mu \mathrm{M}$, SlCsp3 outcompeted the BCA ligand for $\mathrm{Cu}^{\mathrm{I}}$ until $>15 \mathrm{Cu}^{\mathrm{I}}$ equivalents, with respect to protein, were added (Figure $5(\mathrm{a})$ and inset). ${ }^{1}$ Upon increasing the BCA concentration $(250-1000 \mu \mathrm{M})$, competition for cuprous ions between SlCsp3 and the BCA ligand was observed, leading to an estimation of maximum $\mathrm{Cu}^{\mathrm{I}}$ occupancy 

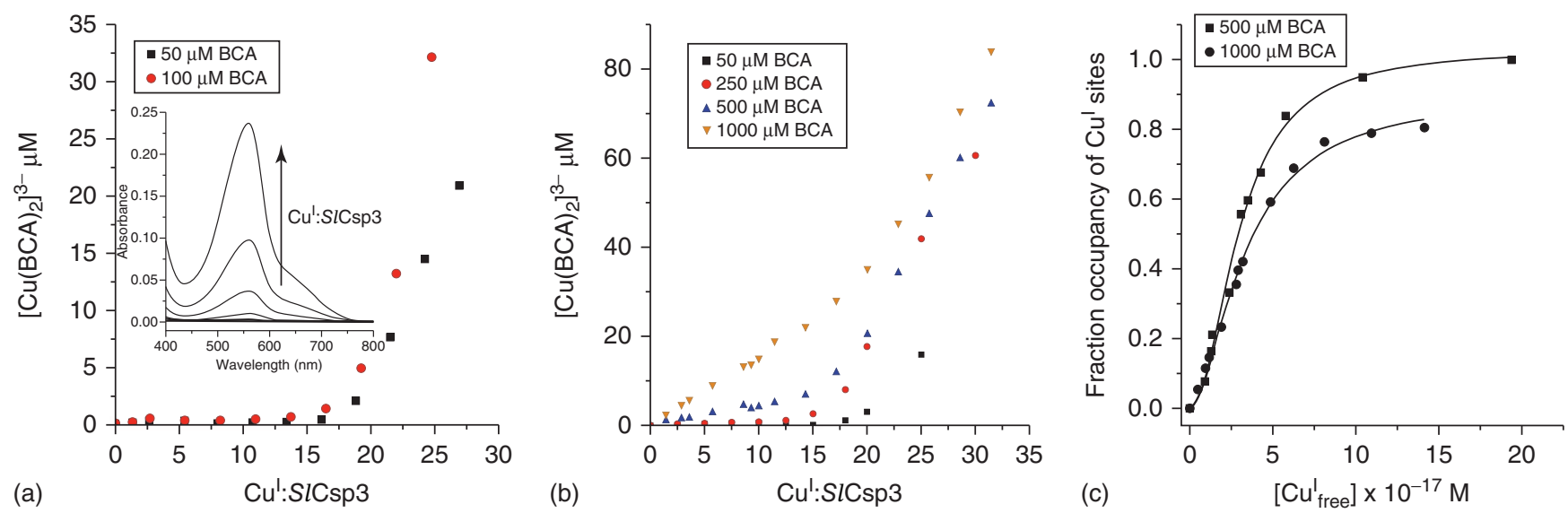

Figure 5 Determining the apparent $\mathrm{Cu}^{\mathrm{I}}$-binding affinity $\left(K_{\mathrm{Cu}}\right)$ of $\operatorname{SlCsp} 3$ at $\mathrm{pH}$ 7.5. (a) Plot of $\left[\mathrm{Cu}(\mathrm{BCA})_{2}\right]^{3-}$ versus the $\mathrm{Cu}{ }^{\mathrm{I}}: \mathrm{SlCsp} 3$ concentration generated from titrating $\mathrm{Cu}^{\mathrm{I}}$ ions into SlCsp3 in the presence of 50 and $100 \mu \mathrm{M}$ BCA. The $\left[\mathrm{Cu}(\mathrm{BCA})_{2}\right]^{3-}$ complex forms after the addition of $15 \mathrm{Cu}^{\mathrm{I}}$ equivalents. Inset, absorbance spectra indicating the formation of the $\left[\mathrm{Cu}(\mathrm{BCA})_{2}\right]^{3-}$ complex upon addition of $\mathrm{Cu}^{\mathrm{I}}$ to $5 \mu \mathrm{M}$ SlCsp3 in the presence of $100 \mu \mathrm{M}$ BCA. (b) As in (a) but with a wider range $(50-1000 \mu \mathrm{M})$ of BCA concentrations, illustrating that as the $[\mathrm{BCA}]$ increases beyond $250 \mu \mathrm{M}$, competition with SlCsp3 for $\mathrm{Cu}^{\mathrm{I}}$ ions occurs. (c) Determination of $K_{\mathrm{Cu}}$ for SlCsp3 from plotting the fractional occupancy of $\mathrm{Cu}^{\mathrm{I}}$-binding sites in SlCsp3 at varying $\left[\mathrm{Cu}_{\text {free }}{ }_{\text {f }}\right.$ ] determined from the plots at 500 and $1000 \mu \mathrm{M} \mathrm{BCA}$ in $(\mathrm{b})$ using Equation 2. Data points have been fitted to the Hill equation. ${ }^{1}$ [Based on ML Straw, AK Chaplin, MA Hough, J Paps, VN Bavro, MT Wilson, E Vijgenboom, JAR Worrall, Metallomics, 10, 180-193 (2018).]

of $\sim 15 \mathrm{Cu}^{\mathrm{I}}$ ions per $\mathrm{SlCsp} 3$ protomer (Figure $\left.5(\mathrm{~b})\right) .{ }^{1}$ Under these experimental conditions, an apparent $\mathrm{Cu}^{\mathrm{I}}-$ binding affinity was determined using two approaches, both of which assume that the following two equilibria are present:

$$
\begin{array}{r}
2 \mathrm{BCA}+\mathrm{Cu}_{\mathrm{f}}^{I} \rightleftharpoons \mathrm{Cu}(\mathrm{BCA})_{2}=K_{\mathrm{BCA}} \\
S_{\mathrm{f}}+\mathrm{Cu}_{\mathrm{f}}^{\mathrm{I}} \rightleftharpoons \mathrm{Cu}^{\mathrm{I}} \mathrm{S}=K_{\mathrm{Cu}}
\end{array}
$$

where BCA is the free ligand, $S_{\mathrm{f}}$ are the sites on $S l \mathrm{Csp} 3$ that are unoccupied with $\mathrm{Cu}^{\mathrm{I}}, \mathrm{Cu}_{\mathrm{f}}^{\mathrm{I}}$ is free cuprous ions, and $K_{\mathrm{BCA}}$ and $K_{\mathrm{Cu}}$ are equilibrium dissociation constants for the affinities of $\mathrm{Cu}^{\mathrm{I}}$ for BCA and SlCsp3, respectively. Based on the above equilibria, the $\left[\mathrm{Cu}_{\mathrm{f}} \mathrm{I}\right]$ is given by

$$
\left[\mathrm{Cu}_{\mathrm{f}}^{\mathrm{I}}\right]=\frac{K_{\mathrm{BCA}}\left[\mathrm{Cu}(\mathrm{BCA})_{2}\right]}{[\mathrm{BCA}]^{2}}=\frac{K_{\mathrm{Cu}}\left[\mathrm{Cu}^{\mathrm{I}} \mathrm{S}\right]}{\left[S_{\mathrm{f}}\right]}
$$

which can be rearranged to solve for $K_{\mathrm{Cu}}$

$$
K_{\mathrm{Cu}}=\frac{K_{\mathrm{BCA}}\left[\mathrm{Cu}(\mathrm{BCA})_{2}\right]\left(\left[S_{\mathrm{t}}\right]-\left[\mathrm{Cu}_{\mathrm{t}}^{\mathrm{I}}\right]+\left[\mathrm{Cu}(\mathrm{BCA})_{2}\right]\right)}{\left(\left[\mathrm{BCA}_{\mathrm{t}}\right]-2\left[\mathrm{Cu}(\mathrm{BCA})_{2}\right]\right)^{2}\left(\left[\mathrm{Cu}_{\mathrm{t}}^{\mathrm{I}}\right]-\left[\mathrm{Cu}(\mathrm{BCA})_{2}\right]\right)}
$$

where $\left[S_{t}\right]$ is the total concentration of sites occupied in $S l \mathrm{Csp} 3,\left[\mathrm{Cu}_{\mathrm{t}}^{\mathrm{I}}\right]$ is the total concentration of cuprous ions added, and $\left[\mathrm{BCA}_{\mathrm{t}}\right]$ is the total concentration of the $\mathrm{BCA}$ ligand in the experiment. Using Equation 1 together with the data reported in Figure 5(b) $(250-1000 \mu \mathrm{M}$ BCA), an average $K_{\mathrm{Cu}}$ for $S l \mathrm{Csp} 3$ of $3.3 \pm 1.3 \times 10^{-17} \mathrm{M}$ has been reported. ${ }^{1}$ Alternatively, at BCA concentrations $\geq 250 \mu \mathrm{M}$, the $K_{\mathrm{Cu}}$ can be determined by calculating the $\left[\mathrm{Cu}_{\mathrm{f}}^{\mathrm{I}}\right]$ using Equation 2,

$$
\left[\mathrm{Cu}_{\mathrm{f}}^{\mathrm{I}}\right]=\frac{\left[\mathrm{Cu}(\mathrm{BCA})_{2}\right]}{\left[\mathrm{BCA}^{*}\right]^{2} \beta_{2}}
$$

where $\left[\mathrm{BCA}^{*}\right]=\left[\mathrm{BCA}_{\mathrm{t}}\right]-2\left[\mathrm{Cu}(\mathrm{BCA})_{2}\right]$, and $\beta_{2}$ is $\log$ 17.7. ${ }^{39}$ Plots of $\left[\mathrm{Cu}_{\mathrm{f}}{ }_{\mathrm{f}}\right]$ against the fractional $\mathrm{Cu}^{\mathrm{I}}$ occupancy of SlCsp3 at a given [BCA] display a sigmodal dependence, which given that the system is at equilibrium implies cooperativity of $\mathrm{Cu}^{\mathrm{I}}$ binding (Figure $\left.5(\mathrm{c})\right) .{ }^{1}$ Using a nonlinear form of the Hill equation, an average $K_{\mathrm{Cu}}$ for BCA concentrations ranging between 250 and $1000 \mu \mathrm{M}$ of $2.9 \pm 0.2 \times 10^{-17} \mathrm{M}$ has been reported together with an average Hill coefficient, $n=1.9 \pm 0.2 .^{1}$

The $K_{\mathrm{Cu}}$ determined for $S l \mathrm{Csp} 3$ is consistent with the subfemtomolar values reported for $B s C s p 3$ and $M t C s p 3,{ }^{4}$ demonstrating that the Cys-lined core of the four-helix bundle is a highly thermodynamically stable scaffold to retain $\mathrm{Cu}^{\mathrm{I}}$ in the reducing environment of the bacterial cytosol. Notably, SlCsp3 is the only Csp3 member so far studied for which cooperativity of $\mathrm{Cu}^{\mathrm{I}}$ binding has been reported. ${ }^{1}$ Cooperativity of cuprous ion binding has been reported for Csp1a, which binds 13 cuprous ions per four-helix bundle. ${ }^{2}$ However, a note a of caution proceeds these observations, given that the $\left[\mathrm{Cu}_{\mathrm{f}}^{\mathrm{I}}\right]$, which are exceedingly low, are calculated indirectly from binding to BCA. ${ }^{1}$ 
The effect of SICsp3 on the copper-dependent morphological development of S. lividans

Streptomycetes undergo a complex development lifecycle on solid substrates such as agar. Following spore germination, a vegetative mycelium is established that through branching results in a large network of hyphae. ${ }^{40,41}$ In response to nutrient depletion and other signals, the initiation of both secondary metabolite production (e.g. compounds that have been found to possess antibiotic, antifungal, and anthelmintic properties) and morphological differentiation occurs. ${ }^{37,42}$ The erection of an aerial mycelium takes place in this next phase, followed by differentiation, which leads to the production of millions of readily dispersible spores. ${ }^{40,41}$ In $S$. lividans, ${ }^{43}$ the bioavailability of copper ions has a strong influence on initiating the morphological switch from the vegetative to the aerial growth phase that coincides with the production of secondary metabolites. ${ }^{44-50}$

Under copper-limiting conditions, two extracytoplasmic copper metallochaperone proteins have been identified, Sco (synthesis of cytochrome c oxidase) and ECuC (extracytoplasmic copper chaperone), that together operate to facilitate delivery of copper to cytochrome c oxidase $(\mathrm{CcO})$ and a novel mononuclear copper-radical oxidase, GlxA (galactose oxidase-like). ${ }^{47-50}$ The enzymatic action of GlxA has been reported to be a key requirement to initiate the copperdependent morphological development switch between vegetative and aerial hyphae. ${ }^{49,50}$ Under copper stress, toxicity in the cytoplasm is precluded through the action of a $\mathrm{Cu}^{\mathrm{I}}$ sensing regulatory transcription factor, ${ }^{51,52}$ which belongs to the copper sensitive operon regulator (CsoR) family. ${ }^{53}$ Cuprous ions that accumulate in the cytosol are 'sensed' by the DNA-bound apo-CsoR, which has an apparent $K_{\mathrm{Cu}}$ of $\sim 10^{-18} \mathrm{M}$ (attomolar) and may be considered as the cytosolic $\mathrm{Cu}^{\mathrm{I}}$ 'set-point' concentration for triggering efflux. ${ }^{51}$ The binding of $\mathrm{Cu}^{\mathrm{I}}$ to the DNA-complexed apo-CsoR allosterically activates transcriptional derepression of three efflux systems, each comprising a $\mathrm{P}_{1}$-type ATPase and a CopZ-like (copper resistance operon) $\mathrm{Cu}^{\mathrm{I}}$ metallochaperone protein that act in synergy to rapidly efflux cuprous ions from the cytosol (see Copper Transporters and Chaperones). ${ }^{51,52,54}$ Thus, to balance the metabolic demands for morphological development and safeguard against $\mathrm{Cu}^{\mathrm{I}}$ toxicity, S. lividans has evolved highly sophisticated metallostasis systems (processes that governs adaptive response to both metal restriction and metal overload) to maintain the cellular copper supply to essential cuproenzymes and protect the organism under copper stress.

To investigate the effect of $S l \mathrm{Csp} 3$ on the copperdependent morphological development and growth of $S$. lividans, a strain in which the $\operatorname{csp} 3$ gene was deleted $(\Delta c s p 3)$ has been constructed. ${ }^{1}$ On solid media (agar plates), growth and development of the $\Delta c s p 3$ strain at exogenous copper concentrations up to $200 \mu \mathrm{M}$ were identical to that of the wild-type (WT) strain (Figure 6(a)). ${ }^{1}$ However, at exogenous copper concentrations $>200 \mu \mathrm{M}$, a clear phenotype for the $\Delta c s p 3$ strain was observed in

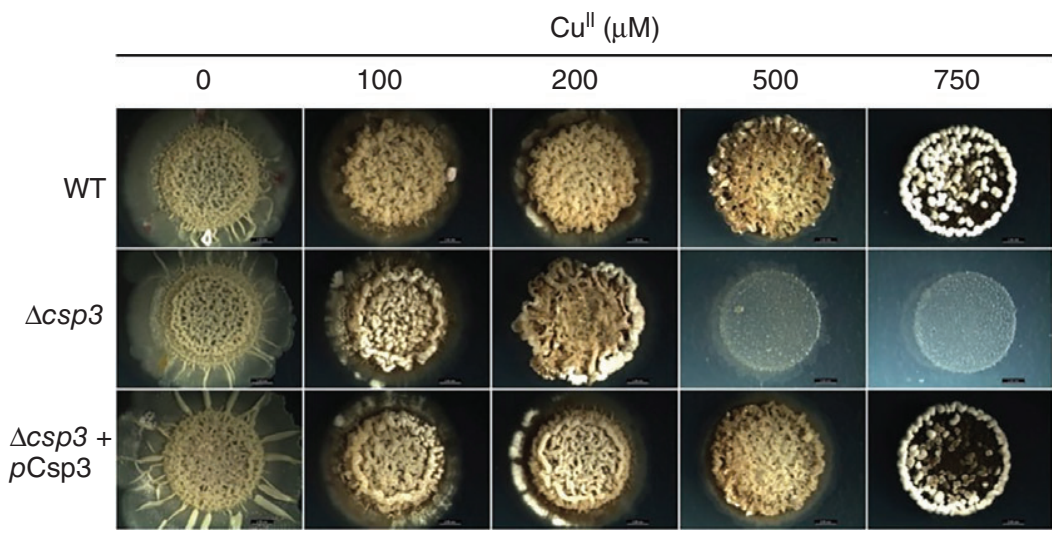

(a)

Figure 6 Functional aspects of SlCsp3 in vivo. (a) Growth and development of the WT strain, the $\Delta c s p 3$ mutant strain, and the $\Delta c s p 3$ mutant strain complemented with the pCsp3 plasmid on defined agar media with glucose as the sole carbon source after six days growth at $30{ }^{\circ} \mathrm{C}$ in the presence of exogenous copper. ${ }^{1}$ [Straw, M. L., Chaplin, A. K., Hough, M. A., Paps, J., Bavro, V. N., Wilson, M. T., ... Worrall, J. A. R. (2018). A cytosolic copper storage protein provides a second level of copper tolerance in Streptomyces lividans. Metallomics, 10(1), 180-193. doi:10.1039/c7mt00299h.] All images are of the same magnification. (b) Representation of the genomic environment (inset) and transcript fold increases determined from RNA-seq analysis of csp3 and the adjacent genes in a liquid-grown S. lividans culture in the presence of $400 \mu \mathrm{M}$ copper. ${ }^{51}$ [Based on Dwarakanath, S.; Chaplin, A. K.; Hough, M. A.; Rigali, S.; Vijgenboom, E.; Worrall, J. A. R. (2012). Response to Copper Stress in Streptomyces lividans Extends beyond Genes under Direct Control of a Copper-sensitive Operon Repressor Protein (CsoR). Journal of Biological Chemistry, 287(21), 17833-17847.]

Encyclopedia of Inorganic and Bioinorganic Chemistry, Online (C) 2011-2021 John Wiley \& Sons, Ltd.

This article is (C) 2021 John Wiley \& Sons, Ltd.

This article was published in the Encyclopedia of Inorganic and Bioinorganic Chemistry in 2021 by John Wiley \& Sons, Ltd.

DOI: 10.1002/9781119951438.eibc2777 
which the development of aerial mycelium and spores is reduced or absent (Figure $6(\mathrm{a}))^{1}{ }^{1}$ Introduction of the $\operatorname{csp} 3$ gene on a plasmid under transcriptional control of its own promoter to the $\Delta c s p 3$ strain leads to a reversal of the phenotype (Figure 6(a)). ${ }^{1}$ Thus, SlCsp3 is clearly required for growth and development of S. lividans at high copper concentrations (between 200 and $500 \mu \mathrm{M}$ external copper, depending on the media used), ${ }^{1}$ but at basal copper levels, the $\Delta c s p 3$ strain mirrors the growth of the parent strain. ${ }^{1}$ To assess whether SlCsp3 influences downstream coppertrafficking pathways in the extracytoplasmic environment under homeostasis, $\mathrm{CcO}$ activity was monitored in the $\Delta c s p 3$ strain. ${ }^{1}$ No discernable differences in $\mathrm{CcO}$ activity for the $\Delta c s p 3$ strain compared to the parent strain were observed. ${ }^{1}$ Under the experimental conditions employed, this observation precludes a downstream role (metabolic) for $\mathrm{SlCsp} 3$ in supplying stored $\mathrm{Cu}^{\mathrm{I}}$ to the extracytoplasmic environment to be utilized by the copper metallochaperones, Sco and ECuC, for metalation of $\mathrm{CcO}$ and GlxA. ${ }^{1}$ In conclusion, the growth studies conducted to date are consistent with a role of $S l C s p 3$ in providing an increased level of copper tolerance in S. lividans and not as a store for metabolic purposes. ${ }^{1}$

\section{Gene environment and transcriptional response under copper stress}

The genomic environment of SlCsp3 (Figure 6(b), inset) reveals two upstream genes predicted to encode for an $\mathrm{Na}^{+} / \mathrm{H}^{+}$antiporter (SLI_RS17245) and a protein of 181 amino acids (SLI_RS17250) that belongs to the DUF4396 superfamily. Immediately downstream from $S l C s p 3$ is a gene annotated to encode for a precorrin- $8 \mathrm{x}$ methyl mutase (SLI_RS17260). Changes in the transcriptome of S. lividans grown under copper stress have been investigated. ${ }^{51}$ Transcript analysis was carried out by ribonucleic acid (RNA)-seq using liquid-defined cultures grown under homeostasis (i.e. basal copper conditions) and in the presence of $400 \mu \mathrm{M}$ copper, with the data revealing an extensive array of up- and downregulated transcripts in response to growth under heightened copper levels. ${ }^{51}$ As expected, genes under the control of the CsoR were significantly upregulated. ${ }^{51}$ Transcript levels for the $\mathrm{Na}^{+} / \mathrm{H}^{+}$ antiporter, DUF4396, and SlCsp3 also increased $\sim$ fivefold, but SLI_RS17260 was unaffected (Figure 6(b)). Notably, the copper-induced expression of the $S l C s p 3$ cluster was at a similar level to that observed for the efflux systems regulated by CsoR (Figure 6(b)). Regulation of SlCsp3 is not under the control of the CsoR, as demonstrated through a lack of a recognizable consensus CsoR-binding site in the $S l \mathrm{Csp} 3$ promoter region ${ }^{1}$ and from the induction of expression in a $\Delta c s o R$ strain of S. lividans. ${ }^{51}$ Together with the observations from the growth assays, the RNAseq data would suggest that once the CsoR/CopZ/P $/ \mathrm{P}_{1}$-type ATPase efflux systems become saturated, a second layer of copper-responsive transcription is operating on top of the CsoR regulon, which expresses $\mathrm{SlCsp} 3$, the $\mathrm{Na}^{+} / \mathrm{H}^{+}$ antiporter, and DUF4396, enabling organism growth at higher copper levels. ${ }^{1}$

\section{A copper metallochaperone can load $\mathrm{Cu}$ ions to apo-SICsp3}

If the function of $\mathrm{SlCsp} 3$ is to assist in copper tolerance and help sequester cuprous ions when the CsoR-regulated efflux systems become saturated, then it can be assumed that $S l C s p 3$ obtains its copper in a controlled manner such as through interaction with either a low-molecular-weight ligand (LMWL), for example mycothiol, the dominant thiol in Actinobacteria that is equivalent to glutathione in other bacteria, ${ }^{55}$ or by a designated protein. Metal trafficking from a donor to an acceptor has been shown in vitro to occur through transient interactions that initiate a ligand-exchange mechanism to facilitate the transfer of the metal (i.e. the metal is never dissociated into solution). ${ }^{56}$ Trafficking of $\mathrm{Cu}^{\mathrm{I}}$ in the cytosol of $S$. lividans under homeostasis and stress has been reported to involve CopZlike $\mathrm{Cu}^{\mathrm{I}}$ metallochaperones. ${ }^{51,52}$ Using a size-exclusion chromatography-based approach, $\mathrm{Cu}^{\mathrm{I}}$-loaded $\mathrm{CopZ}$ has been shown to transfer copper to $\mathrm{SlCsp3}$, but $\mathrm{Cu}^{\mathrm{I}}$-loaded SlCsp3 cannot transfer $\mathrm{Cu}^{\mathrm{I}}$ to $\mathrm{CopZ}$, at least under the stoichiometric conditions employed. ${ }^{1}$ Thus, the ability of CopZ to safely 'off-load' its copper cargo fits with the view obtained from in vivo and transcriptional studies that the $S l$ Csp3 can assist in increasing the copper tolerance levels of S. lividans.

\section{FUNCTIONAL DERIVATIVES}

Understanding the kinetic and thermodynamic intricacies associated with $\mathrm{Cu}^{\mathrm{I}}$ loading to $\mathrm{SlCsp} 3$ is particularly challenging, considering the number of distinct binding sites that $\mathrm{Cu}^{\mathrm{I}}$ thiolate chemistry can allow. The in vitro mechanism of cuprous ion loading to $\mathrm{SlCsp3}$ has been investigated using X-ray crystallography, stopped-flow kinetics, and site-directed mutagenesis. ${ }^{57}$

\section{Visualization of $\mathrm{Cu}^{\prime}$ loading to SICsp3 through X-ray crystallography}

X-ray crystal structures of $S l C s p 3$ have been determined following the addition of substoichiometric equivalents (5and 10 - equivalents) of cuprous ions. ${ }^{57}$ For 5 - equivalents, anomalous electron density associated with bound cuprous ions was only observed in the outer core (Figure 7(a)), revealing two types of multinuclear copper clusters. ${ }^{57}$ Both clusters are dominated by group II and III coordination 


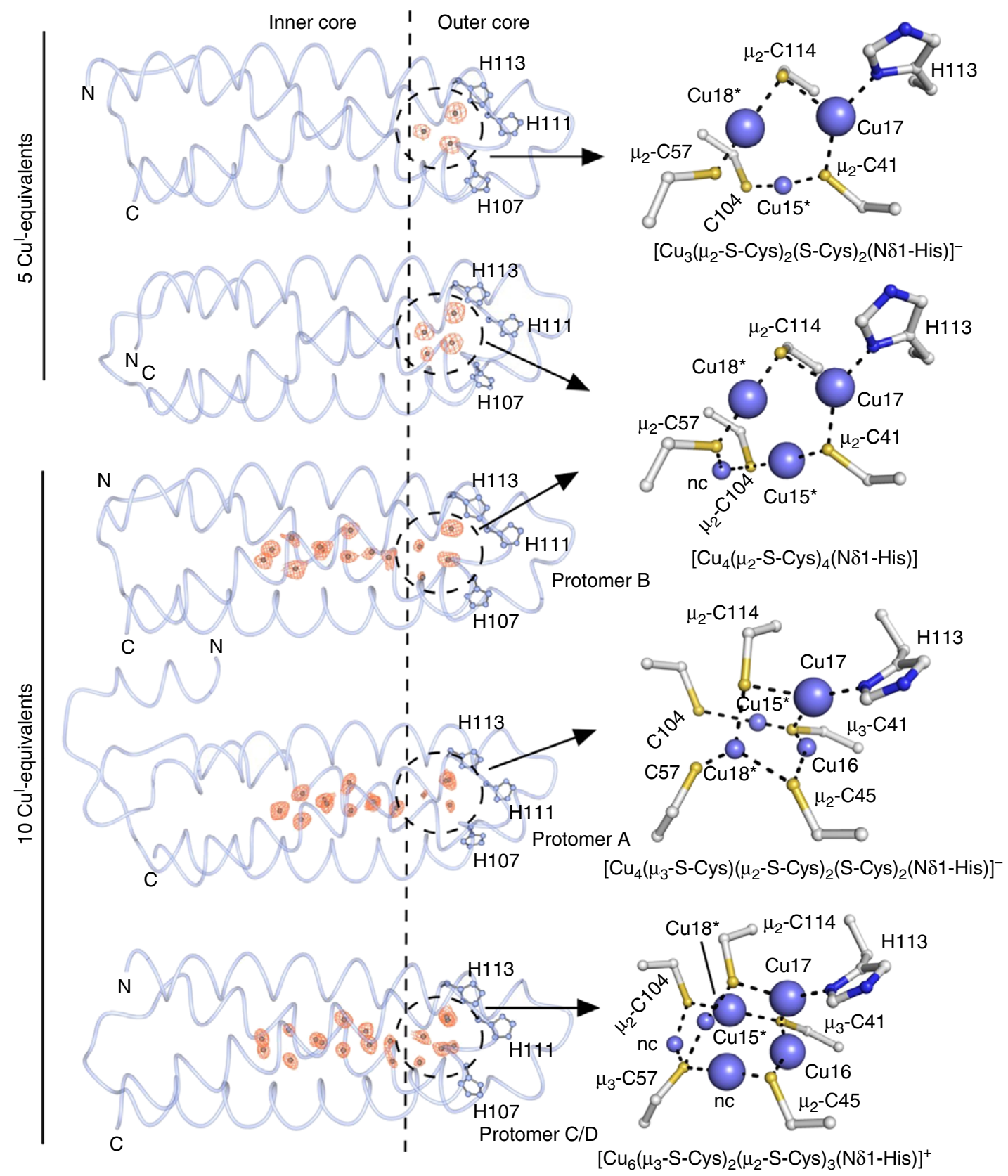

(a)

(b)

Figure 7 Visualization of $\mathrm{Cu}^{\mathrm{I}}$ sites and polynuclear $\mathrm{Cu}^{\mathrm{I}}$ clusters upon partial $\mathrm{Cu}^{\mathrm{I}}$ loading of $S l \mathrm{Csp}$. (a) X-ray structures indicating the distribution of the coordinated $\mathrm{Cu}^{\mathrm{I}}$ ions (silver spheres) following addition of 5 or $10 \mathrm{Cu}^{\mathrm{I}}$ equivalents. Worm representation of individual protomers found in the respective crystallographic asymmetric unit following addition of 5 or $10 \mathrm{Cu}^{\mathrm{I}}$ equivalents, with the anomalous electron density (orange mesh) revealing the location of coordinated cuprous ions. The His residues at the outer core entrance are depicted in sticks and labeled. (b) Ball-and-stick representation of the various polynuclear $\mathrm{Cu}^{\mathrm{I}}$ clusters identified in the outer core of the protomers (dashed circle in (a)). [Straw, Megan L., Hough, Michael A., Wilson, Michael T., Worrall, Jonathan A.R. (2019). A histidine residue and a tetranuclear cuprous-thiolate cluster dominate the copper loading landscape of a copper storage protein from Streptomyces lividans. Chemistry - A European Journal, 25, 10678-10688.]

chemistry, creating a negatively charged trinuclear $\left[\mathrm{Cu}_{3}\left(\mu_{2}-\right.\right.$ $\mathrm{S}$-Cys $)_{2}(\mathrm{~S} \text {-Cys })_{2}(\mathrm{~N} \delta 1$-His $\left.)\right]^{-}$cluster (observed in one protomer of the crystallographic asymmetric unit) and a neutral, tetranuclear $\left[\mathrm{Cu}_{4}\left(\mu_{2}-\mathrm{S}-\mathrm{Cys}\right)_{4}(\mathrm{~N} \delta 1-\mathrm{His})\right]$ cluster (observed in three of the protomers in the crystallographic asymmetric unit) (Figure $7(\mathrm{a})$ and (b))..$^{57}$ The latter is symmetrical in that all Cys thiolates are bridging ( $\left.\mu_{2}-\mathrm{S}-\mathrm{Cys}\right)$ $\mathrm{a} \mathrm{Cu}^{\mathrm{I}}$ ion, whereas in the trinuclear cluster, the symmetry 
is broken as two Cys thiolates display monodentate $\mathrm{Cu}^{\mathrm{I}}$ coordination (Figure $7(\mathrm{~b})$ ). In both clusters, only one cuprous ion occupies a binding site observed in the fully $\mathrm{Cu}^{\mathrm{I}}$-loaded protein (Cu17). ${ }^{57}$ Two cuprous ions, although occupying similar positional locations to $\mathrm{Cu} 15$ and $\mathrm{Cu} 18$ in the fully $\mathrm{Cu}^{\mathrm{I}}$-loaded structure, are distinct in that they have an altered coordination sphere and have been designated $\mathrm{Cu} 15 *$ and $\mathrm{Cu} 18 * .57$ The fourth cuprous ion in the tetranuclear cluster is coordinated at a site which is absent in the fully $\mathrm{Cu}^{\mathrm{I}}$-loaded protein and has been designated as a noncognate site and possesses group II coordination (Figure $7(\mathrm{~b})) .{ }^{57}$ In the trinuclear cluster, Cu15* has a lower occupancy than either $\mathrm{Cu} 17$ or $\mathrm{Cu} 18^{*}$, while in the tetranuclear cluster, the noncognate copper has the lowest occupancy, ${ }^{57}$ suggesting that the trinuclear cluster is an intermediate on route to forming the tetranuclear cluster. ${ }^{57}$ Furthermore, sites $1-14$ in the inner core remain unoccupied and suggest that the tetranuclear $\left[\mathrm{Cu}_{4}\left(\mu_{2}-\mathrm{S}\right.\right.$ Cys) $\left.{ }_{4}(\mathrm{~N} \delta 1-\mathrm{His})\right]$ cluster must be thermodynamically more favored than occupancy of sites in the inner core, at least under low $\mathrm{Cu}^{\mathrm{I}}$ ratios. ${ }^{57}$

The $10 \mathrm{Cu}^{\mathrm{I}}$-equivalents structure reveals more sites occupied than $\mathrm{Cu}^{\mathrm{I}}$ equivalents added, indicating that some of the sites are not fully occupied (Figure $7(\mathrm{a})) .{ }^{57}$ Of the four protomers present in the crystallographic asymmetric unit, protomers A and B revealed electron density for 14 cuprous ions, with protomer A having all cuprous ions occupying cognate sites, while protomer B possesses two cuprous ions occupying noncognate sites. ${ }^{57}$ In protomers C and D, anomalous electron density was observed for 18 cuprous ions. Copper sites 1, 2, and 4, located at the bottom of the inner core, remain unoccupied in all protomers, as do $\mathrm{Cu}$ sites 19 and $20 .^{57}$ The observation of different distributions and occupancies of cuprous ions within the inner and outer cores of SlCsp3 reflect transient intermediates in the site occupancies during the $\mathrm{Cu}^{\mathrm{I}}$-loading process. ${ }^{57}$ Notably, the polynuclear copper clusters identified in the outer core of the 5-equivalent structure also dominate in the 10-equivalents structure (Figure $7(\mathrm{~b})) .{ }^{57}$ In protomer $\mathrm{B}$, the neutral symmetrical tetranuclear copper cluster is present (Figure $7(\mathrm{~b})$ ). However, in protomer A, a new asymmetric negatively charged tetranuclear $\left[\mathrm{Cu}_{4}\left(\mu_{3}-\mathrm{S}\right.\right.$ Cys) $\left.\left(\mu_{2}-\mathrm{S} \text {-Cys }\right)_{2}(\mathrm{~S}-\mathrm{Cys})_{2}(\mathrm{~N} \delta 1-\mathrm{His})\right]^{-}$cluster is observed (Figure $7(\mathrm{~b})$ ), whereas in protomers $\mathrm{C}$ and $\mathrm{D}$, the tetranuclear clusters observed in protomers $\mathrm{A}$ and $\mathrm{B}$ combine with a second noncognate cuprous ion to form a positively charged hexanuclear $\left[\mathrm{Cu}_{6}\left(\mu_{3}-\mathrm{S} \text {-Cys }\right)_{2}\left(\mu_{2} \text {-S-Cys }\right)_{3}(\mathrm{~N} \delta 1-\right.$ His) $]^{+}$cluster (Figure $7(\mathrm{~b})$ ). Thus, as more $\mathrm{Cu}^{\mathrm{I}}$ ions are loaded to SlCsp3, the outer core displays coordination promiscuity, enabling the formation of various polynuclear clusters, which are not observed in the inner core.

\section{Stopped-flow kinetics to monitor Cu' loading to SICsp3}

Stopped-flow absorption spectroscopy has demonstrated that complete loading of aqueous $\mathrm{Cu}^{\mathrm{I}}$ to $\mathrm{SlCsp3}$ is accomplished within the first $2 \mathrm{~s}$ of the reaction time course (Figure $8(\mathrm{a})) .{ }^{57}$ For complete loading to occur within $2 \mathrm{~s}$,
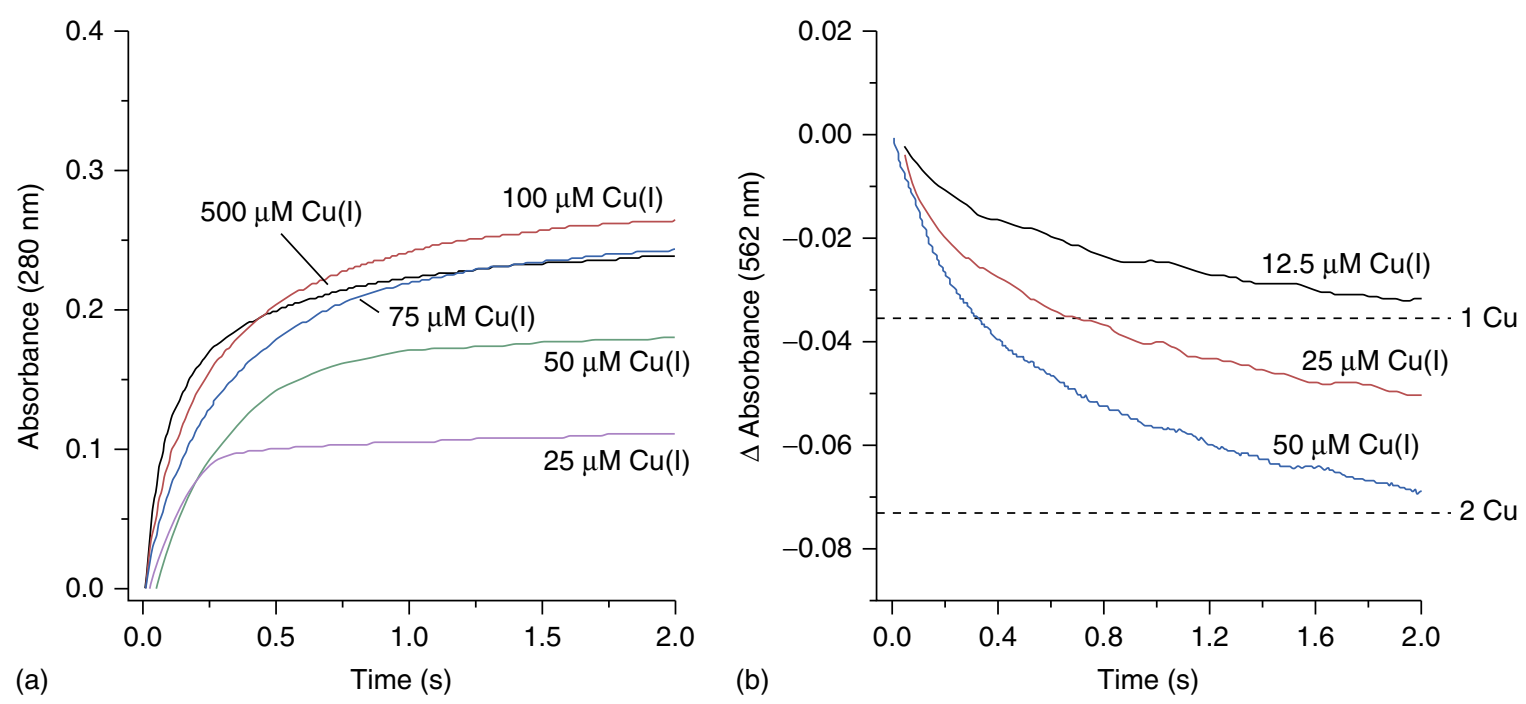

Figure 8 Kinetic time courses upon mixing various concentrations of aqueous $\mathrm{Cu}^{\mathrm{I}}$ (a) and the $\left[\mathrm{Cu}(\mathrm{BCA})_{2}\right]^{3-} \operatorname{complex}(\mathrm{b})$ with $\mathrm{SlCsp} 3$ in a stopped-flow spectrophotometer. In both the cases, the initial fast phase over the first $2 \mathrm{~s}$ of the reaction is depicted. In (b), the dashed lines indicate the expected absorbance changes for removal of $\mathrm{Cu}^{\mathrm{I}}$ equivalents from the $\left[\mathrm{Cu}(\mathrm{BCA})_{2}\right]^{3-}$ complex. Experiments were carried out at $20^{\circ} \mathrm{C}$ at pH 7.5. ${ }^{57}$ [Straw, Megan L., Hough, Michael A., Wilson, Michael T., Worrall, Jonathan A.R. (2019). A histidine residue and a tetranuclear cuprous-thiolate cluster dominate the copper loading landscape of a copper storage protein from Streptomyces lividans. Chemistry - A European Journal, 25, 10678-10688.] 
the individual binding sites within the four-helix bundle, although having a high intrinsic affinity for cuprous ions, must be able to pass $\mathrm{Cu}^{\mathrm{I}}$ ions between sites, suggesting that an internal ligand-exchange-type mechanism is operating. ${ }^{57}$ Based on the kinetics of $\mathrm{Cu}^{\mathrm{I}}$ loading, this would mean that the half-life for $\mathrm{Cu}^{\mathrm{I}}$ dissociation from any site within the core of the four-helix bundle will be $\ll 2 \mathrm{~s}^{57}$

The kinetics of $\mathrm{Cu}^{\mathrm{I}}$ loading to $S l \mathrm{Csp} 3$ from a donor, BCA, have also been investigated using stopped-flow. ${ }^{57}$ These studies revealed a rapid decrease in absorbance of the $562 \mathrm{~nm}$ peak of the $\left[\mathrm{Cu}(\mathrm{BCA})_{2}\right]^{3-}$ complex, within the first $2 \mathrm{~s}$ of the reaction, when mixing fixed concentrations of $\left[\mathrm{Cu}(\mathrm{BCA})_{2}\right]^{3-}$ with $\mathrm{SlCsp} 3 .{ }^{57}$ The amplitude of this absorbance change was found to be $\left[\mathrm{Cu}(\mathrm{BCA})_{2}\right]^{3-}$ concentration dependent, ${ }^{57}$ and depending on the $\left[\mathrm{Cu}(\mathrm{BCA})_{2}\right]^{3-}$ concentration mixed, between 1 and $2 \mathrm{Cu}^{\mathrm{I}}$ ions were found to be loaded to $S l \mathrm{Csp} 3$ within the 2-s time period (Figure 8(b)). ${ }^{57}$ Notably, over a time base of 500 s, multiple kinetic processes comprising at least three exponential phases were observed. ${ }^{57}$ Such complexity in the kinetics must arise from the cuprous ions being delivered from the $\left[\mathrm{Cu}(\mathrm{BCA})_{2}\right]^{3-}$ complex one at a time and involve (i) complex formation between $\mathrm{SlCsp} 3$ and $\left[\mathrm{Cu}(\mathrm{BCA})_{2}\right]^{3-}$, (ii) $\mathrm{Cu}^{\mathrm{I}}$ transfer, and (iii) dissociation of the free BCA ligand. ${ }^{57}$ Thus, the kinetic data imply a sequential mechanism of $\mathrm{Cu}^{\mathrm{I}}$ loading to $\mathrm{SlCsp3}$, which is initiated through the transfer of a cuprous ion from a donor to a first coordination site in $\mathrm{SlCsp3}$, followed by the passage of cuprous ions from site to site within the core of the four-helix bundle. ${ }^{57}$

\section{The role of the outer core His residues in $\mathrm{Cu}^{\mathrm{l}}$ loading}

When $\mathrm{SlCsp} 3$ is fully $\mathrm{Cu}^{\mathrm{I}}$ loaded (20 cuprous ions), all three His residues at the entrance to the outer core participate in group III coordination (Figure $4\left(\right.$ b)). ${ }^{1}$ When partially loaded (5 or $10 \mathrm{Cu}^{\mathrm{I}}$ equivalents added), His113 coordinates a cuprous ion, whereas His107 and His111 do not, implying a role for His107 and His111 in initial $\mathrm{Cu}^{\mathrm{I}}$ capture. ${ }^{57}$ Using site-directed mutagenesis to create the H107A, H111A, H113A, and H107A/H111A variants, the role that these His residues play in $\mathrm{Cu}^{\mathrm{I}}$ loading has been elucidated. ${ }^{57}$ The X-ray crystal structures for the fully $\mathrm{Cu}^{\mathrm{I}}$ loaded, H111A, H113A, and H107/H111A variants have been determined, with all three structures revealing electron-density for copper sites 1-14 (inner core) with identical coordination chemistry as found in the WT protein. ${ }^{57}$ In the outer core, an additional non-cognate $\mathrm{Cu}^{\mathrm{I}}$ ion is present in all three variants adjacent to $\mathrm{Cu} 15$ (Figure 9(a)), with coordination from the OS atom of Asp61 and the $S \gamma$ atom of Cys57, creating a new group III coordination site. ${ }^{57}$ No electron density was visible for $\mathrm{Cu} 19$ and $\mathrm{Cu} 20$ in the H111A and H107A/H111A structures (Figure 9(a)), thus supporting a role for these residues in initial $\mathrm{Cu}^{\mathrm{I}}$ loading and also indicating their requirement in enabling a maximum of 20 cuprous ions to bind per fourhelix bundle.

Stopped-flow kinetic studies of $\mathrm{Cu}^{\mathrm{I}}$ loading to the His variants using $\mathrm{BCA}$ as the $\mathrm{Cu}^{\mathrm{I}}$ donor revealed rapid transfer (again within the first $2 \mathrm{~s}$ ) of $\mathrm{Cu}^{\mathrm{I}}$ from the $\left[\mathrm{Cu}(\mathrm{BCA})_{2}\right]^{3-}$ complex to the H111A and H113A variants (Figure 9(b)). ${ }^{57}$ In contrast, the $\mathrm{H} 107 \mathrm{~A}$ and $\mathrm{H} 107 \mathrm{~A} / \mathrm{H} 111 \mathrm{~A}$ variants both demonstrated a pronounced decrease in the rate of $\mathrm{Cu}^{\mathrm{I}}$ entry, implying that His107 has a major role in the initial loading of $\mathrm{Cu}^{\mathrm{I}}$ to $\mathrm{SlCsp} 3$ (Figure 9(b)). ${ }^{57}$ Furthermore, the H107A variant was additionally found to slow subsequent $\mathrm{Cu}^{\mathrm{I}}$ transfer (i.e. after initial loading), which was also the case for the H111A variant, whereas the double variant $(\mathrm{H} 107 \mathrm{~A} / \mathrm{H} 111 \mathrm{~A})$ affected both the initial $\mathrm{Cu}^{\mathrm{I}}$ loading (His107) and subsequent transfer (His107 and His111). ${ }^{57}$ Finally, the kinetics of the H113A variant were identical to the WT protein corroborating structural interpretation that His113 impairs neither the initial $\mathrm{Cu}^{\mathrm{I}}$ binding nor subsequent transfer to other available sites.

\section{A mechanism for $\mathrm{Cu}^{\prime}$ loading to SICsp3}

Based on the available kinetic, structural, and site-directed mutagenesis data, a mechanistic model accounting for $\mathrm{Cu}^{\mathrm{I}}$ loading to $S l C s p 3$ using the $\left[\mathrm{Cu}(\mathrm{BCA})_{2}\right]^{3-}$ complex as $\mathrm{Cu}^{\mathrm{I}}$ donor has been proposed. ${ }^{57}$ The model describes the relative energy of binding to the $\mathrm{Cu}^{\mathrm{I}}$ sites in $S l C s p 3$ and illustrates the relative stability of the complexes of $\mathrm{Cu}^{\mathrm{I}}$ in the sites described (Figure 10). ${ }^{57}$ On mixing the coordinatively saturated $\left[\mathrm{Cu}(\mathrm{BCA})_{2}\right]^{3-}$ complex with SlCsp3, a heteroleptic complex forms, consisting of $[\mathrm{Cu}(\mathrm{BCA})]^{-}$and a nitrogen from a His residue, with the net loss of a BCA ligand (Figure 10). The His residue involved in this heteroleptic complex is His 107 based on the large effect its removal has on the kinetics of the initial fast phase of $\mathrm{Cu}^{\mathrm{I}}$ loading. ${ }^{57}$ Furthermore, the effect His107 has on the initial $\mathrm{Cu}^{\mathrm{I}}$ loading can be accounted for by the requirement for a transient ([Cu(BCA) $]^{-}:$His-SlCsp3) complex to form and then dissociate after each $\mathrm{Cu}^{\mathrm{I}}$ ion is donated. ${ }^{57}$ An energetically favored transfer to sites 19 and 20 then follows before moving on to sites $15^{*}, 17$, and $18^{*}$ to form first, the trinuclear and then the more thermodynamically stable tetranuclear cluster (Figures 7(b) and 10). On doing so, His107 is released from coordination and enables further $\mathrm{Cu}^{\mathrm{I}}$ capture from the donor (His-ligand cycle, Figure 10). Removing His107 and His111 revealed that the movement of $\mathrm{Cu}^{\mathrm{I}}$ ions beyond sites 19 and 20 following the initial binding is slowed. This is accounted for by His107 and His111 acting to stabilize $\mathrm{Cu}^{\mathrm{I}}$ binding to sites 19 and 20, which when absent destabilizes these sites and hinders subsequent loading, which must occur via sites 19 and 20, followed by transfer into the outer core. ${ }^{57}$

Under low $\mathrm{Cu}^{\mathrm{I}}$ stoichiometries, the formation of the neutral $\left[\mathrm{Cu}_{4}\left(\mu_{2} \text {-S-Cys }\right)_{4}(\mathrm{~N} \delta 1\right.$-His $\left.)\right]$ cluster creates an unfavorable barrier to loading into the inner core. To load $\mathrm{Cu}^{\mathrm{I}}$ 

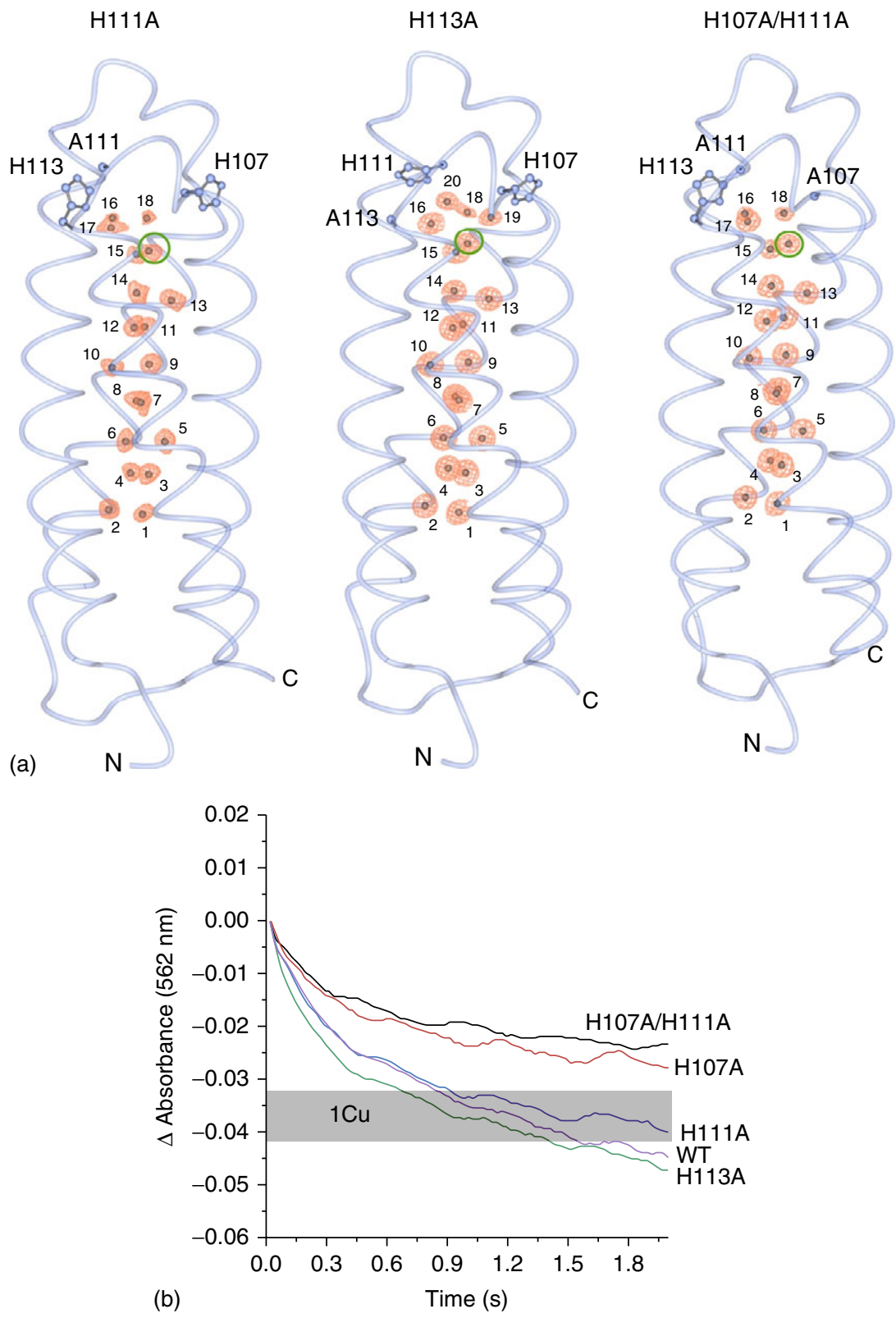

Figure 9 X-ray structures and stopped-flow absorbance kinetics of the SlCsp3 His variants. (a) Worm representations of each His variant with the anomalous electron density for the bound $\mathrm{Cu}^{\mathrm{I}}$ ions shown in orange mesh. The green circles indicate the location of the noncognate $\mathrm{Cu}^{\mathrm{I}}$-binding sites. (b) Reaction time course, illustrating the initial fast phase, on mixing the WT SlCsp3 and each His variant with the $\left[\mathrm{Cu}(\mathrm{BCA})_{2}\right]^{3-}$ complex $(50 \mu \mathrm{M})$. Shaded area indicates the expected absorbance changes for removal of one $\mathrm{Cu}^{\mathrm{I}}$ equivalent from the $\left[\mathrm{Cu}(\mathrm{BCA})_{2}\right]^{3-}$ complex based on the variation of protein concentrations used in the experiment $\left(20^{\circ} \mathrm{C}, \mathrm{pH} 7.5\right) .{ }^{57}[\mathrm{Modified} \mathrm{from}$ Straw, Megan L., Hough, Michael A., Wilson, Michael T., Worrall, Jonathan A.R. (2019). A histidine residue and a tetranuclear cuprousthiolate cluster dominate the copper loading landscape of a copper storage protein from Streptomyces lividans. Chemistry - A European Journal, 25, 10678-10688.]

into the inner core via sites 14 and 15 , interaction with the OS atoms of Asp61 must occur (Asp sites, Figure 10). A hard ligand/soft metal interaction is less favored and of lower affinity than the $\mathrm{Cu}^{\mathrm{I}}$ thiolate coordination dominating the tetranuclear cluster. However, as more $\mathrm{Cu}^{\mathrm{I}}$ is loaded into the outer core, this barrier is seemingly overcome, leading to transfer into the inner core becoming favorable. The visualization of $\mathrm{Cu}^{\mathrm{I}}$ loading to $\mathrm{M} t \mathrm{Csp} 3$ has also been reported, with several X-ray structures determined following the addition of substoichiometric cuprous ions (Table 1).33 Interestingly, for $M t C s p 3$, tetranuclear copper cluster formation $\left[\mathrm{Cu}_{4}\left(\mu_{2}-\mathrm{S} \text {-Cys }\right)_{4}\right]$ is also observed at low $\mathrm{Cu}^{\mathrm{I}}$ stoichometries. ${ }^{33}$ However, these clusters form in the inner core, as opposed to the outer core as observed 


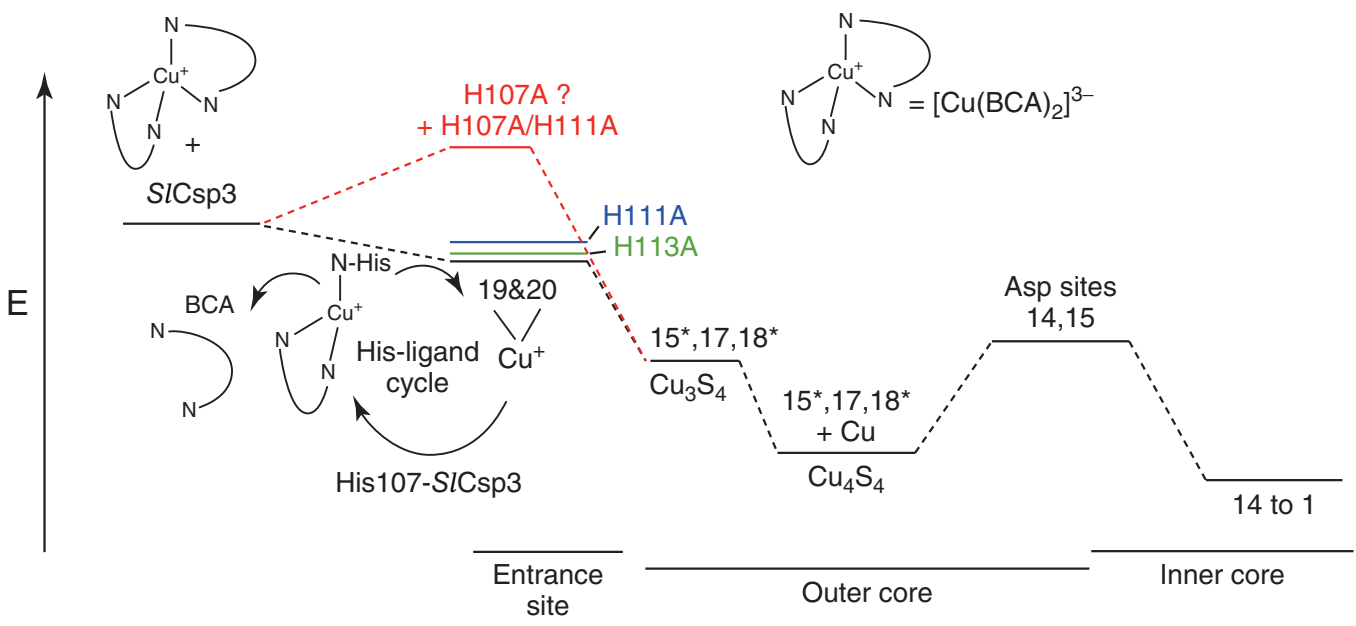

Figure 10 A model to account for the kinetic, structural, and site-directed mutagenesis data obtained for $\mathrm{Cu}^{\mathrm{I}}$ loading to $\mathrm{SlCsp} 3$ from the $\left[\mathrm{Cu}(\mathrm{BCA})_{2}\right]^{3-}$ complex. ${ }^{57}$ The relative stabilities of the copper sites are depicted relative to an arbitrary energy scale $(E)$. [Straw, Megan L., Hough, Michael A., Wilson, Michael T., Worrall, Jonathan A.R. (2019). A histidine residue and a tetranuclear cuprousthiolate cluster dominate the copper loading landscape of a copper storage protein from Streptomyces lividans. Chemistry - A European Journal, 25, 10678-10688.]

for $\mathrm{SlCsp} 3 .^{57}$ A reason for this difference is not immediately apparent, although it is noted that in $M t$ Csp3 the Asp residue found in $\mathrm{SlCsp} 3$ at the interface between the outer and inner core is replaced with an Asn residue. ${ }^{4}$ Thus, based on the $\mathrm{Cu}^{\mathrm{I}}$ loading model reported for $\mathrm{SlCsp3}$, the absence of the negatively charged bidentate Asp residue in $M t C s p 3$ could remove the barrier to populating the inner core under low $\mathrm{Cu}^{\mathrm{I}}$ stoichiometries. Regardless of these differences, a common theme appears in that the driving force to sequester $\mathrm{Cu}^{\mathrm{I}}$ and prevent toxicity in Csp3 members is through initial formation of tetranuclear $\mathrm{Cu}^{\mathrm{I}}$-thiolate clusters. ${ }^{33,57}$

\section{RELATED ARTICLES}

Particulate Methane Monooxygenase; Methane Monooxygenase Hydroxylase; Ferritin; $b$-Type Cytochrome Electron Carriers: Cytochromes $b_{562}$ and $b_{5}$, and Flavocytochrome $b_{2}$; Copper Transporters and Chaperones

\section{REFERENCES}

1 ML Straw, AK Chaplin, MA Hough, J Paps, VN Bavro, MT Wilson, E Vijgenboom and JAR Worrall, Metallomics, 10, 180-93 (2018).

2 N Vita, S Platsaki, A Basle, SJ Allen, NG Paterson, AT Crombie, JC Murrell, KJ Waldron and C Dennison, Nature, 525, 140-3 (2015).

3 C Dennison, S David and J Lee, J Biol Chem, 293, 4616-27 (2018).
$4 \quad$ N Vita, G Landolfi, A Basle, S Platsaki, J Lee, KJ Waldron and C Dennison, Sci Rep, 6, 39065 (2016).

5 S Sirajuddin and AC Rosenzweig, Biochemistry, 54, 2283-94 (2015).

6 TJ Lawton and AC Rosenzweig, J Am Chem Soc, 138, 9327-40 (2016).

7 SH Stanley, SD Prior, DJ Leak and H Dalton, Biotechnol Lett, 5, 487-92 (1983).

8 RL Lieberman and AC Rosenzweig, Nature, 434, 177-82 (2005).

9 R Balasubramanian, SM Smith, S Rawat, LA Yatsunyk, TL Stemmler and AC Rosenzweig, Nature, 465, 115-9 (2010).

10 SY Ro, LF Schachner, CW Koo, R Purohit, JP Remis, GE Kenney, BW Liauw, PM Thomas, SM Patrie, NL Kelleher and AC Rosenzweig, Nat Commun, 10, 2675 (2019).

11 MO Ross, F MacMillan, J Wang, A Nisthal, TJ Lawton, BD Olafson, SL Mayo, AC Rosenzweig and BM Hoffman, Science, 364, 566-70 (2019).

12 AC Rosenzweig, CA Frederick, SJ Lippard and P Nordlund, Nature, 366, 537-43 (1993).

13 JD Lipscomb, Annu Rev Microbiol, 48, 371-99 (1994).

14 SD Prior and H Dalton, J Gen Microbiol, 131, 155-63 (1985).

15 AK Nielsen, K Gerdes, H Degn and JC Murrell, Microbiology, 142, 1289-96 (1996).

16 AK Nielsen, K Gerdes and JC Murrell, Mol Microbiol, 25, 399-409 (1997).

17 GE Kenney, M Sadek and AC Rosenzweig, Metallomics, 8, 931-40 (2016).

18 DW Choi, RC Kunz, ES Boyd, JD Semrau, WE Antholine, JI Han, JA Zahn, JM Boyd, AM de la Mora and AA DiSpirito, J Bacteriol, 185, 5755-64 (2003).

19 M Martinho, DW Choi, AA Dispirito, WE Antholine, JD Semrau and E Münck, J Am Chem Soc, 129, 15783-5 (2007).

20 R Balasubramanian and AC Rosenzweig, Curr Opin Chem Biol, 12, 245-9 (2008). 
21 GE Kenney and AC Rosenzweig, ACS Chem Biol, 7, 260-8 (2012).

22 AA DiSpirito, JD Semrau, JC Murrell, WH Gallagher, C Dennison and S Vuilleumier, Microbiol Mol Biol Rev, 80, 387-409 (2016).

23 C Dennison, Chemistry, 25, 74-86 (2019).

24 JM Arguello, D Raimunda and T Padilla-Benavides, Front Cell Infect Microbiol, 3, 73 (2013).

25 H Irving and RJP Williams, Nature, 162, 746-7 (1948).

26 L Macomber and JA Imlay, Proc Natl Acad Sci U S A, 106, 8344-9 (2009).

27 S Chillappagari, A Seubert, H Trip, OP Kuipers, MA Marahiel and M Miethke, J Bacteriol, 192, 2512-24 (2010).

28 DK Fung, WY Lau, WT Chan and A Yan, J Bacteriol, 195, 4556-68 (2013).

29 G Tan, Z Cheng, Y Pang, AP Landry, J Li, J Lu and H Ding, Mol Microbiol, 93, 629-44 (2014).

30 C Rademacher and B Masepohl, Microbiology, 158, 2451-64 (2012).

31 J Lee and C Dennison, Int J Mol Sci, 20, 4144 (2019).

32 Z Xiao, PS Donnelly, M Zimmermann and AG Wedd, Inorg Chem, 47, 4338-47 (2008).

33 A Basle, S Platsaki and C Dennison, Angew Chem Int Ed, 56, 8697-700 (2017).

34 E Krissinel and K Henrick, J Mol Biol, 372, 774-97 (2007).

35 DM Lawson, PJ Artymiuk, SJ Yewdall, JM Smith, JC Livingstone, A Treffry, A Luzzago, S Levi, P Arosio, G Cesareni, CD Thomas, WV Shaw and PM Harrison, Nature, 349, 541-4 (1991).

36 FS Mathews, PH Bethge and EW Czerwinski, J Biol Chem, 254, 1699-706 (1979).

37 KF Chater, Philos Trans $R$ Soc Lond Ser B Biol Sci, 361, 761-8 (2006).

38 Z Xiao and AG Wedd, Nat Prod Rep, 27, 768-89 (2010).

39 P Bagchi, MT Morgan, J Bacsa and CJ Fahrni, J Am Chem Soc, 135, 18549-59 (2013).

40 K Flardh and MJ Buttner, Nat Rev Microbiol, 7, 36-49 (2009).
41 D Claessen, DE Rozen, OP Kuipers, L Sogaard-Andersen and GP van Wezel, Nat Rev Microbiol, 12, 115-24 (2014).

42 GP van Wezel and KJ McDowall, Nat Prod Rep, 28, 1311-33 (2011).

43 J Anne, B Maldonado, J Van Impe, L Van Mellaert and K Bernaerts, J Biotechnol, 158, 159-67 (2012).

44 BJ Keijser, GP van Wezel, GW Canters, T Kieser and E Vijgenboom, J Mol Microbiol Biotechnol, 2, 565-74 (2000).

45 JAR Worrall and E Vijgenboom, Nat Prod Rep, 27, 742-56 (2010).

46 M Fujimoto, A Yamada, J Kurosawa, A Kawata, T Beppu, H Takano and K Ueda, Microbiol Biotechnol, 5, 477-88 (2012).

47 KLM Blundell, MT Wilson, DA Svistunenko, E Vijgenboom and JAR Worrall, Open Biol, 3, 12016 (2013).

48 KLM Blundell, MA Hough, E Vijgenboom and JAR Worrall, Biochem J, 459, 525-38 (2014).

49 AK Chaplin, ML Petrus, G Mangiameli, MA Hough, DA Svistunenko, P Nicholls, D Claessen, E Vijgenboom and JAR Weorrall, Biochem J, 469, 433-44 (2015).

50 ML Petrus, E Vijgenboom, AK Chaplin, JAR Worrall, GP van Wezel and D Claessen, Open Biol, 6, 150149 (2016).

51 S Dwarakanath, AK Chaplin, MA Hough, S Rigali, E Vijgenboom and JAR Worrall, J Biol Chem, 287, 17833-47 (2012).

52 AK Chaplin, BG Tan, E Vijgenboom and JAR Worrall, Metallomics, 7, 145-55 (2015).

53 T Liu, A Ramesh, Z Ma, SK Ward, L Zhang, GN George, AM Talaat, JC Sacchettini and DP Giedroc, Nat Chem Biol, 3, 60-8 (2007).

54 BG Tan, E Vijgenboom and JAR Worrall, Nucleic Acids Res, 42, 1326-40 (2014).

55 GL Newton, N Buchmeier and RC Fahey, Microbiol Mol Biol Rev, 72, 471-94 (2008).

56 L Banci, I Bertini, F Cantini, IC Felli, L Gonnelli, N Hadjiliadis, R Pierattelli, A Rosato and P Voulgaris, Nat Chem Biol, 2, 367-8 (2006).

57 ML Straw, MA Hough, MT Wilson and JAR Worrall, Chemistry, 25, 10678-88 (2019). 